\title{
Olive tree physiology and chemical composition of fruits are modulated by different deficit irrigation strategies
}

\author{
Alexandre Gonçalves ${ }^{1,2}$, Ermelinda Silva ${ }^{1}$, Cátia Brito ${ }^{1}$, Sandra Martins ${ }^{1}$, Luís Pinto ${ }^{1}$, \\ Lia-Tânia Dinis ${ }^{1}$, Ana Luzio ${ }^{1}$, Carlos Martins-Gomes ${ }^{3}$, Anabela Fernandes-Silva ${ }^{1}$, \\ Carlos Ribeiro ${ }^{4}$, M. Ângelo Rodrigues ${ }^{5}$, José Moutinho-Pereira ${ }^{1}$, Fernando M. Nunes ${ }^{2}$, \\ Carlos M. Correia ${ }^{1 *}$ \\ ${ }^{1}$ CITAB - Centre for the Research and Technology of Agro-Environmental and \\ Biological Sciences, Universidade de Trás-os-Montes e Alto Douro, 5000-801 Vila \\ Real, Portugal;
}

${ }^{2}$ MORE - Research Mountains - Association, Brigantia Ecopark, 5300-358 Bragança, Portugal

${ }^{3}$ CQVR - Chemistry Centre of Vila Real, Universidade de Trás-os-Montes e Alto Douro, 5000-801 Vila Real, Portugal;

${ }^{4}$ Agronomy Department, University of Trás-os-Montes and Alto Douro, Quinta dos Prados, 5000-801 Vila Real

${ }^{5}$ Centro de Investigação de Montanha (CIMO), Instituto Politécnico de Bragança, Campus de Santa Apolónia, 5300-253 Bragança, Portugal

*Corresponding author:

Carlos M. Correia

Phone: $+351-259350235$;

E-mail: ccorreia@utad.pt

This article has been accepted for publication and undergone full peer review but has not been through the copyediting, typesetting, pagination and proofreading process which may lead to differences between this version and the Version of Record. Please cite this article as doi: 10.1002/jsfa.10064 


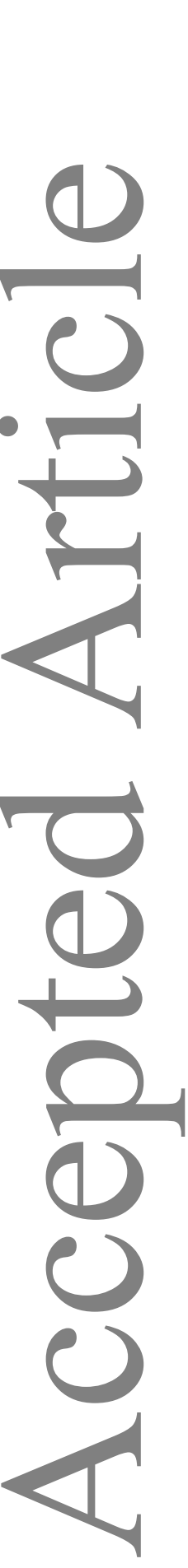

Abstract

\section{BACKGROUND}

To overcome constrains affecting olive groves, cropping practices focusing on agronomic water use efficiency and their impact on quality parameters must be investigated. We evaluated the response of olive trees (Olea europaea, cv. Cobrançosa) to different water regimes, full irrigation (FI, 100\% ETc) and three deficit irrigation strategies (DIS) (regulated (RDI, irrigated with $80 \%$ of crop evapotranspiration $\left(\mathrm{ET}_{\mathrm{c}}\right)$ in phases I and III of fruit growth and $10 \%$ of $\mathrm{ET}_{\mathrm{c}}$ in the pit hardening stage) and two continuous sustained strategies (SDI), a conventional SDI (27.5\% of $\mathrm{ET}_{\mathrm{c}}$ ), and a lowfrequency irrigation adopted by the farmer (SDIAF, 21.2\% of $\mathrm{ET}_{\mathrm{c}}$ ).

\section{RESULTS}

The effects of water regimes on the plant water status, photosynthetic performance, metabolites fluctuations and fruit quality parameters were evaluated. All DIS treatments enhanced leaf tissue density, RDI and SDI generally did not affect leaf water status and maintained photosynthetic machinery working properly, while SDIAF treatment impaired olive tree physiological indicators. DIS treatments maintained the levels of primary metabolites in leaves, but SDIAF plants showed signs of oxidative stress. Moreover, DIS treatments led to changes in the secondary metabolism, both in leaves and in fruits, with increased total phenolic compounds, ortho-diphenols, and flavonoids concentrations, and higher total antioxidant capacity, as well higher oil content. Phenolic profiles showed the relevance of an early harvest in order to obtain higher oleuropein levels with associated higher health benefits.

\section{CONCLUSION}

Adequate DIS are essential for sustainable olive growing, as they enhance the competitiveness of the sector in terms of olive production and associated quality parameters.

Keywords: Ecophysiology; Fruit physicochemical properties; Irrigation regime; Olea europaea; Water use efficiency. 


\section{INTRODUCTION}

The Mediterranean Basin is a climate change and biodiversity hot spot where substantial warming and lower water availability is predicted for the next few decades. ${ }^{1}$ The magnitude of the predicted climate change in natural and agro-ecosystems poses considerable challenges to their management. In olive tree, an ancient crop with considerable ecological and socioeconomic importance in the Mediterranean area, the impacts derived from climate warming might lead to areas of decreased profitability. ${ }^{2}$ Mediterranean crops, like olive trees, intrinsically have several protection mechanisms against the typical summer stress (drought, heat and high irradiation levels). However, extreme water-limited environments due to climate change may come with negative repercussions on minerals uptake, carbon assimilation, canopy dimension, oxidative susceptibility, phenology, growth and reproduction processes and, consequently, on crop yield. $^{3-5}$

Due to the diversity in microclimate, soils and rainfall patterns in Mediterranean olive growing areas, annual crops water needs range extensively. Moreover, although olive trees are known to be resistant to drought, irrigation has been shown to improve the physiological performance of the trees, including better water status, higher stomatal conductance and photosynthetic rates, and the crop yield. ${ }^{3,5-9}$ Nonetheless, irrigation has also been shown to have negative effects on both oil yield and quality, as the percentage of oil in the fruit has been reported to decrease as a function of increased amounts of applied water, ${ }^{8}$ affecting both the total amount of phenolic compounds and the HPLC profiles present in virgin olive oils, changing the olive oil stability to autoxidation, the sensory quality and ultimately consumer acceptance. ${ }^{10}$

Irrigation strategies require precise knowledge of crop response to water deficit, which vary according to the specific genotype and during different phenological stages. $^{11}$ In this sense, deficit irrigation strategies (DIS), an agronomic practice that 
consist in the application of water below the $\mathrm{ET}_{\mathrm{c}}$ requirements, has been extensively researched in fruit trees with reported positive yields and quality responses. ${ }^{12,13}$ DIS can also allow to control excessive vegetative vigour and minimize minerals losses through leaching, while improve crop water use efficiency. ${ }^{14}$

Different DIS have shown beneficial effects on fruit yield, being sustained deficit irrigation (SDI) and regulated deficit irrigation (RDI) two of the most common strategies. ${ }^{15,16}$ In SDI, a constant application of a reduced amount of water, which can be defined as over $75 \%$ to less than $25 \%$ of the crop evapotranspiration $\left(\mathrm{ET}_{\mathrm{c}}\right)$, leads to a slow gradual increase of water deficit as the season advances, allowing plants to adapt to it. ${ }^{17}$ For instance, it has been shown that for a Californian high-density hedgerow 'Arbequina' olive orchard, fruit yield could be maximized with a SDI strategy using 70 to $75 \%$ of $\mathrm{ET}_{\mathrm{c}}$, being the best results in olive oil chemical parameters, flavour and stability achieved with 33 to $40 \%$ of $\mathrm{ET}_{\mathrm{c}} \cdot{ }^{18,19}$ In olive trees, the main objective of RDI is not to control vegetative growth, since shoot growth occurs mainly in spring and slightly in autumn. Additionally, it has been noticed that deficit irrigation significantly reduces the final yield if applied in spring, from budburst until fruit drop, and in late summer during fruit oil synthesis. Conversely, if applied during summer, specifically during the fruit pit-hardening phase, deficit irrigation could result in lower reduction in fruit and oil yield. ${ }^{20,21}$ Moreover, a deficit irrigation system usually contributes to change the pomological characteristics, as well the chemical composition of fruits, with consequences at commercial, nutritional and sensorial levels ${ }^{9,}{ }^{22}$. Consequently, the cultivar, environmental conditions, management practices, among other factors, must be taken into account when studying the effect of DIS on plant phenology, growth, carbon assimilation, water use efficiency and also their impact on olive fruit yield and quality. ${ }^{3,}$ $17,21,23$ 
Due to the importance of the cv. Cobrançosa in Portuguese young olive orchards owing the high productivity and regularity and relatively high oil yields (18-22\%), the lack of knowledge in the response of this cultivar to deficit irrigation strategies, particularly the physiological, leaves and fruits biochemical parameters, and in order to overcome constrains that affect olive groves and its socioeconomic value, research focusing on agronomic water use efficiency must be explored. Hence, in this work we aimed to understand the response of 8 years old "cv. Cobrançosa" olive trees to three deficit irrigation strategies, RDI and 2 SDI treatments, in order to optimize the use of water in crop production. To accomplish this objective, we studied the irrigation regimes effect on the plant water status, photosynthetic performance, foliar primary and secondary metabolites fluctuations, and fruit yield as well as quality parameters. 


\section{MATERIAL AND METHODS}

\section{Site description, cultural practices and plant material}

The experimental trial was conducted in Lodões, Vila Flor, Northeast Portugal, at Quinta do Prado farm (41 $\left.200^{\prime} 13.3^{\prime \prime} \mathrm{N}, 7^{\circ} 05^{\prime} 54.2^{\prime \prime} \mathrm{W}\right)$, during the 2016 cropping season, on an organic 8-years-old olive orchard (Olea europaea L. cv. "Cobrançosa") planted in rows $7 \mathrm{~m}$ apart, at a tree spacing of $3.80 \mathrm{~m}$, with a plantation density of 376 plants per hectare. "Cobrançosa" is a traditional Portuguese Cultivar, native of Trás-osMontes Region, and mainly cultivated for oil production. Trees presented an ellipsoid shape, with a mean volume of $9 \mathrm{~m}^{3}$. A moderate pruning, performed annually in the winter resting period, removed around $20 \%$ of foliage.

The field trial was carried out in a eutric Cambisol. ${ }^{24}$ The soil is loamy textured (61.7\% sand, $18.3 \%$ silt, and $20.0 \%$ clay), alkaline (pH 8.0) and showed mean levels of organic carbon (24.8 $\mathrm{g} \mathrm{kg}^{-1}$, Walkley-Black). Phosphorus and potassium levels were very high (respectively 226.5 and $230.0 \mathrm{mg} \mathrm{kg}^{-1}$, as determined by Egnér-Riehm method), as well as exchangeable calcium and magnesium (25.0 and $6.2 \mathrm{cmol}_{\mathrm{c}} \mathrm{kg}^{-1}$, respectively, as determined by the ammonium acetate method). Leaf analysis revealed an orchard in good nutritional status, with all the essential elements falling within the sufficiency ranges established for the species. $^{25}$ No soil mineral fertilization was applied. The soil was managed without mobilizations and a rotary brush cutter was used once in May to reduce soil cover vegetation.

The climate is a typically Mediterranean-like, classified as Csa according Köppen-Geiger climatic classification. ${ }^{26}$ Environmental conditions were representative of the area with a typical warm temperate dry summer with a summer reference evapotranspiration $\left(\mathrm{ET}_{\mathrm{o}}\right)$ of $488 \mathrm{~mm}$. Global solar radiation, minimum and maximum air temperature and precipitation recorded during the experimental period are shown in Table 1. 


\section{Treatments applied and monitoring}

Different irrigation treatments were imposed in July $15^{\text {th }} 2016$. The volume of water applied was quantified by estimating $\mathrm{ET}_{\mathrm{c}}$ according to the FAO method proposed by Doorenbos and Pruitt $(1977),{ }^{27}$ employing the crop coefficient $\left(K_{c}=0.45\right)$ and a tree ground cover coefficient $(\mathrm{Kr})$ of 0.17 estimated with mean crop diameter measured with a ruler. ${ }^{28}$ Reference evapotranspiration $\left(\mathrm{ET}_{\mathrm{o}}\right)$ was calculated according to Allen et al. ${ }^{29}$, using meteorological data from a weather station located near the experiment. The crop coefficient used for the irrigation period was obtained following previous measurements of evapotranspiration using the soil water balance approach in the same cultivar and region. ${ }^{30,31}$ This value presents a good agreement with the estimated value $(\mathrm{y}=0.91 \mathrm{x}+0.12 ; \mathrm{r} 2=0.95)$ of $\mathrm{Kc}$ by the model of Orgaz et al. ${ }^{31}$ Accordingly, three irrigation regimes were applied: a fully irrigated control (FI) that receive a seasonal water amount equivalent to $100 \%$ of $\mathrm{ET}_{\mathrm{c}}$; a sustained deficit irrigation (SDI) treatment corresponding to $27.5 \%$ of $\mathrm{ET}_{\mathrm{c}}$; a regulated deficit irrigation (RDI) treatment corresponding to $80 \%$ of $\mathrm{ET}_{\mathrm{c}}$ in phases I and III of fruit growth and $10 \%$ of $\mathrm{ET}_{\mathrm{c}}$ in phase II, the pit hardening stage. These irrigation treatments were compared with a sustained deficit irrigation treatment applied by the farmer (SDIAF), a variant of SDI that incorporates a low-frequency irrigation during the whole irrigation season, which had been defined as irrigation of three hours per week, independently of environmental conditions during the whole irrigation season, which corresponded to a seasonal water amount equivalent to $21.2 \%$ of the volume of water of FI irrigation. The low-frequency deficit irrigation, a practice commonly used in regions where water is particularly scarce, was similar to the conventional irrigation regime in the study area, which may allow farmers to have more flexibility in managing their irrigation systems and to avoid 
additional expenses of automating the system. The trees were drip-irrigated by three drippers per tree (two at $1.5 \mathrm{~m}$ from the trunk and one near the trunk), each with a flow rate of $1.8 \mathrm{~L} / \mathrm{h}$, connected to a single drip line. The $\mathrm{ET}_{\mathrm{o}}$, rainfall and the irrigation water applied to each treatment are shown in Table 1.

The experimental trial included four adjacent plots, one per irrigation regime, each with four rows, with 18 olive trees per row, where only the two central lines per treatment were used for analysis, while the others two outer rows were considered buffer zones and excluded in sampling to avoid edge effects. Briefly, a total of 20 olive trees of similar canopy size were used per treatment. All the physiological and biochemical analysis done at leaf level were taken in healthy, fully expanded and mature leaves of each plant $(n=20)$. Leaf gas exchange was taken periodically during the morning period (9:00 - 10: 30 a.m) and leaf relative water content was evaluated at midday period. The leaf samples for biochemical analysis were collected at the severest analysed period (August $17^{\text {th }}$ ).

\section{Leaf water status and leaf density}

Leaves samples, detached in a similar sunny position, were immediately placed into air-tight containers and the following parameters were examined: fresh weight (FW; g); leaf area (LA), measured with an LI-3100 leaf area meter (Li-Cor, Lincoln, $\mathrm{NE}$ ); fresh weigh at full turgor (TW; g), measured after immersion of leaf petioles in demineralized water for $48 \mathrm{~h}$ in the dark at $4{ }^{\circ} \mathrm{C}$; and dry weight (DW; g), measured after drying in a force-draft oven at $60{ }^{\circ} \mathrm{C}$ to a constant weight. This procedure allowed to calculate the leaf relative water content $(\mathrm{RWC}=(\mathrm{FW}-\mathrm{DW}) /(\mathrm{TW}-\mathrm{DW}) \times 100)$ and the leaf density $(\mathrm{D}=(\mathrm{DW} / \mathrm{FW}) * 1000)$. 


\section{Leaf gas exchange}

Leaf gas exchange parameters were measured using a portable IRGA (LCpro+, ADC, Hoddesdon, UK), operating in the open mode. Measurements were performed on cloudless days under natural irradiance and environmental conditions on sun exposed leaves. Net photosynthetic rate $\left(\mathrm{A}, \mu \mathrm{mol} \mathrm{CO}_{2} \mathrm{~m}^{-2} \mathrm{~s}^{-1}\right)$, stomatal conductance $\left(\mathrm{g}_{\mathrm{s}}, \mathrm{mmol}\right.$ $\left.\mathrm{m}^{-2} \mathrm{~s}^{-1}\right)$ and the ratio of intercellular to atmospheric $\mathrm{CO}_{2}$ concentration $\left(\mathrm{C}_{\mathrm{i}} / \mathrm{C}_{\mathrm{a}}\right)$ were assessed following previously developed equations. ${ }^{32}$ Intrinsic water use efficiency was calculated as the ratio of $\mathrm{A} / \mathrm{g}_{\mathrm{s}}\left(\mu \mathrm{mol} \mathrm{mol}{ }^{-1}\right)$.

\section{Foliar pigments, metabolites and oxidative stress indicators}

Chlorophylls $\left(\mathrm{Chl}_{\mathrm{a}}\right.$ and $\left.\mathrm{Chl}_{\mathrm{b}}\right)$ and total carotenoids (Car) were extracted with $80 \%(\mathrm{v} / \mathrm{v})$ acetone and determined according to previously published methodologies. ${ }^{33-}$ ${ }^{35} \beta$-carotene was determined through extraction with a acetone-hexane mixture (4:6). ${ }^{36}$

Total soluble proteins (TSP) was quantified using the method of Bradford (1976), using bovine serum albumin as a standard. TSP extract was used to assess total thiols (-SH) using an extinction coefficient of $13,600 \mathrm{M}^{-1} \mathrm{~cm}^{-1} 37$

The content of total phenolic compounds (TPC) and the concentration of orthodiphenol compounds (ODC) were determined in methanolic extract following the Folin-Ciocalteu procedure and the sodium molybdate reagent, respectively. ${ }^{38,39}$ Gallic acid was used as standard. Flavonoids were determined according to previously published methodologies and using (+)-catechin as standard. ${ }^{40}$

The radical-scavenging activity was determined by the 2,2-azino-bis(3ethylbenzothiazoline)-6 sulfonic acid (ABTS) radical cation decolourization assay. Briefly, for this assay $\mathrm{ABTS}^{+}$radical was prepared by mixing an ABTS stock solution with $2.45 \mathrm{mM}$ potassium persulfate. The $\mathrm{ABTS}^{+}$solution was diluted with $20 \mathrm{mM}$ 
sodium acetate buffer $(\mathrm{pH} 4.5)$ to an absorbance of $0.70 \pm 0.01$ at $734 \mathrm{~nm}$. The reaction was started by the addition of $25,50,100,150$ and $200 \mu \mathrm{L}$ of the methanolic extract to 2 $\mathrm{mL}$ of the diluted $\mathrm{ABTS}^{+}$solution. $\mathrm{ABTS}^{+}$bleaching was monitored at $734 \mathrm{~nm}$ at $25{ }^{\circ} \mathrm{C}$ for at least $30 \mathrm{~min}$ and the percentage of discoloration after $15 \mathrm{~min}$ was used as the measure of antioxidant activity. The total antioxidant capacity (TAC) of the extract was calculated as Trolox Equivalent Antioxidant Capacity (TEAC) and was expressed as mmol of Trolox equivalents (TE) per $\mathrm{kg}$ of sample (dry weight). All measurements were performed in triplicate. A standard curve of the percentage of $\mathrm{ABTS}^{+}$inhibition in function of Trolox concentration ( 0.11 to $0.014 \mathrm{mM})$ was used for the calculations. ${ }^{41}$

Total soluble sugars (SS) were extracted by heating the samples in $80 \%$ ethanol during $1 \mathrm{~h}$, at $80^{\circ} \mathrm{C}$. Then, the soluble fraction was separated from the solid fraction and the SS concentration was determined by the anthrone method, using glucose as a standard. $^{42}$

\section{Fruit sampling and maturation index}

Samples of olive fruits for biochemical analysis were collected at three different dates dates $\left(29^{\text {th }}\right.$ September and $11^{\text {th }}$ and $25^{\text {th }}$ October $)$ during the last month of fruit maturation, preceding the traditional harvest time for this particular olive grove (end of October). Olives were collected around the circumference of the tree, at the same height, from 20 trees per treatment and were preserved at $-80{ }^{\circ} \mathrm{C}$ for chemical determination. The fruit maturation index was determined according to the method proposed by the National Institute of Agronomic Research of Spain, relying primarily

on the extent of the epidermis and mesocarp colour. ${ }^{43}$ Additionally, the fruit colour was monitored with a colorimeter Minolta CR-300 (USA). Measurements were made in the middle zone of fruit and the CIELab chromatic system was applied to analyse the 
colour. Results were expressed by luminosity coordinates $\left(\mathrm{L}^{*}\right)$, chroma $\left(\mathrm{C}^{*}\right)$ and tonality $\left(\mathrm{h}^{\mathrm{o}}\right){ }^{44}$

A puncture test was performed in 30 fresh olive fruits per treatment using a SMS $\mathrm{P} / 2 \mathrm{~N}$ needle probe and a $5 \mathrm{~kg}$ load cell in a texture analyser (Stable Micro Systems Surrey, UK). For this test the olives were punctured in the lateral face with the probe speed at $1.0 \mathrm{~mm} \mathrm{~s}^{-1}$ and the penetration depth limited to $3 \mathrm{~mm}$. The force-time curve was graphically acquired and elaborated. The olive peel break force (yield point), as the maximum force $(\mathrm{N})$ reached during puncturing was considered. ${ }^{45}$

\section{Fruit fat content and fatty acid profile}

For determination of the olive fruit fat content and succeeding fatty acid profile, fruits were subjected to Folch's extraction procedure with some adaptations. ${ }^{46,} 47$ Briefly, $2 \mathrm{~g}$ of olive flesh dried samples (Ps) were added to $50 \mathrm{ml}$ of Folch's solutions (chloroform/methanol $(2: 1 ; \mathrm{v} / \mathrm{v})+50 \mathrm{mg} / \mathrm{L}$ butylated hydroxytoluene $(\mathrm{BHT}))$ and mechanical homogenization using an ultra-turrax for 6 minutes on ice was performed. The crude extract was filtered and added to a separating funnel and the procedure repeated. After the two procedures, the volume in the separating funnel was adjusted to $150 \mathrm{~mL}$ with Folch's solutions and then $37,5 \mathrm{~mL}$ of $\mathrm{NaCl}(0.73 \%)$ was added. After mixing it, was let resting overnight. The lower phase was collected to previously weighted glass flasks (P0) and the solvent was evaporated using a rotary evaporator. After placed $24 \mathrm{~h}$ in a desiccator, the flasks were reweighed (P1) and the sample fat content calculated $($ Fat content $(\%)=(\mathrm{P} 1-\mathrm{P} 0) / \mathrm{Ps} * 100)$.

The fatty acid (FA) composition of the former extracted lipid fractions were determined by gas chromatographic analysis following conversion of the free FAs released to their methyl esters (FAME) ${ }^{48}$ After derivatization, chromatographic analysis 
was performed on a Trace GC gas chromatograph equipped with a flame ionization detector (FID) and Autosampler, fitted with a fused silica capillary column (SupelcowaxTM 10, with 30 m length x $0.25 \mathrm{~mm}$ ID and $0.25 \mu \mathrm{m}$ film thickness). $1 \mu \mathrm{L}$ of each sample was injected. Oven temperature was maintained 2 minutes at $100^{\circ} \mathrm{C}$, followed by a gradient from $100{ }^{\circ} \mathrm{C}$ to $220^{\circ} \mathrm{C}$ (at $4^{\circ} \mathrm{C} / \mathrm{min}$ rate) and holded at $220^{\circ} \mathrm{C}$ for 20 minutes, to a total run time of 52 minutes. The injector (splitless) and detector temperatures were $250^{\circ} \mathrm{C}$. The carrier gas was helium at a flow rate of $1 \mathrm{~mL} / \mathrm{min}$. Peaks were tentatively identified by comparing the relative retention times with those from reference standard mixtures (Sigma-Aldrich, USA) run on the same column under the same conditions. All samples were run in triplicate and the results were expressed in relative percentage for each FA, calculated by internal normalization of the chromatographic peak area. The FAs composition for each sample was presented in terms of saturated acids: myristic acid (C14:0), palmitic (C16:0), arachidic (C20:0), behenic (C22:0) and unsaturated acids: monounsaturated fatty acids (MUFAs) palmitoleic (C16:1), oleic (C18:1), gondoic acid (C20:1), erucic acid (C22:1); and polyunsaturated fatty acids (PUFAs) - linoleic (C18:2), linolenic (C18:3), and arachidonic acid (C20:2). Values presented are the average values of three individual samples, each sample analysed in triplicate.

\section{Polyphenolic compounds extraction and quantification in fruits}

Lyophilised olive fruits flesh (2 g) were macerated with $30 \mathrm{~mL}$ of a mixture of MeOH: $\mathrm{H}_{2} \mathrm{O}$ (50:50) and incubated at room temperature for $30 \mathrm{~min}$. After a centrifugation at $10000 \mathrm{~g}$ for $10 \mathrm{~min}$, the supernatant was decanted and extractions were repeated three times. To remove the fat phase, the mixture was washed twice with hexane $(50 \mathrm{~mL})$ using a separating funnel and the organic phase discarded. Each extract 
was introduced into a glass flask and the volume adjusted to $200 \mathrm{~mL}$ with $\mathrm{MeOH}: \mathrm{H}_{2} \mathrm{O}$ (50:50). Three replicates per sample were performed.

For the TPC, ortho-diphenol and flavonoids concentrations, and ABTS activity determinations were employed the same methodologies used for the leaves (session 2.5).

\section{Determination of the polyphenolic profile of the olive fruits by HPLC}

For this analysis, $100 \mathrm{~mL}$ of olive flesh methanolic extract obtained in 2.8 were concentrated under vacuum by rotary evaporator at $35{ }^{\circ} \mathrm{C}$. After evaporation, the contents were redissolved in $5 \mathrm{~mL}$ of $\mathrm{MeOH}: \mathrm{H}_{2} \mathrm{O}$ (50:50).

The chromatographic analysis of the polyphenolic compounds was accomplished by reversed phase (C18) high performance liquid chromatography using an Ultimate 3000 HPLC (Dionex, USA), equipped with Ultimate 3000 pump and column compartment, a WPS-3000 TSL Analyt auto sampler and a PDA-100 UV-Vis photodiode array detector. ${ }^{49}$ The compounds separation was achieved by gradient elution on an ACE 5 C18 column, $5 \mu \mathrm{m}$ particle size $(250 \mathrm{~mm} \times 4.6 \mathrm{~mm})$ (Advanced Chromatography Technologies, Scotland), and the analysis conditions were set with solvent A (95:5 water/formic acid (v/v)), solvent B (methanol), and a linear gradient analysis for a total run time of $80 \mathrm{~min}$ used as follows: starting from $5 \%$ solvent $\mathrm{B}$ during $2 \mathrm{~min}$, increase to $80 \%$ solvent B over $68 \mathrm{~min}$, isocratic for $8 \mathrm{~min}$, decreasing to $5 \%$ solvent B over $2 \mathrm{~min}$, and last isocratic for $5 \mathrm{~min}$. The sample volume injected was $50 \mu \mathrm{L}$, the flow rate was $1.0 \mathrm{~mL} / \mathrm{min}$, and the column temperature maintained at $30{ }^{\circ} \mathrm{C}$. The eluent was continuously monitored from 200 to $600 \mathrm{~nm}$ with a photodiode array detector (PDA-100, Dionex). Data acquisition, analysis and peak integration were performed using Chromeleon software (Version 7.1; Dionex, USA). ${ }^{50}$ 
For the identification of the polyphenolic profile available commercial standards (Sigma-Aldrich, USA and Extrasynthese, France) of apigenin, apigenin-7-O-glucoside, caffeic acid, chlorogenic acid, epicatechin, (-) epigallocatechin, eriodyctiol-7-Oglucoside, (-) gallocatechin, hydroxitirosol, kaempferol-3-O-glucoside, kaempferol-7$O$-glucoside, luteolin-3,7-di- $O$-glucoside, luteolin-7- $O$-glucoside, myricetin-3-O glucoside, oleuropein, procyanidin $\mathrm{A} 2$, procyanidin $\mathrm{B} 1$, procyanidin $\mathrm{B} 2$, quercetin-3-Oglucoside, quercetin-3,7-di- $O$-glucoside, rutin, and verbascoside were used. Standard curves were prepared in a concentration range of 5-500 $\mathrm{mg} / \mathrm{L}$ using the wavelength of maximum absorption of each phenolic compound. The presence or absence of a particular polyphenolic compound was assessed by comparison of the retention time and UV-Vis spectra.

\section{Statistical analyses}

The statistical analysis was performed using the statistical software program SPSS for Windows (v. 22). ANOVA analysis of the experimental data was conducted to estimate the effects of the irrigation treatments. Significant differences between means were determined using the Tukey's test at $\mathrm{P}<0.05$. 


\section{RESULTS}

\section{Leaf water status and gas exchange}

Deficit irrigation strategies influenced RWC (Figure 1). In general, all the newly applied irrigation treatments improved plant water status in relation to the irrigation adopted by the farmer (SDIAF). RDI plants maintained RWC values at FI level, while SDI and SDIAF treatments consistently showed lower RWC values than FI trees. The irrigation regimes also influenced leaf density (Figure 1). On August $3^{\text {rd }}$, none of the newly applied irrigation systems induced changes in relation to SDIAF plants, whereas RDI treatment presented leaves with higher density than SDI plants. Meanwhile, on August $31^{\text {st }}$, although no significant differences were recorded between the newly applied irrigation treatments, the leaf density of FI and RDI plants were lower than on SDIAF trees. On October $11^{\text {th }}$, all DIS plants presented similar leaf density, which was higher than on FI leaves.

As illustrated in Figure 2, the irrigation regimes also influenced leaf gas exchange responses. In general, all the newly irrigation treatments presented higher A and $g_{s}$ than SDIAF plants, being the values of RDI and SDI trees similar to FI plants. An exception to this trend was verified at September $19^{\text {th }}$, where SDI presented higher A and gs than RDI trees. Meanwhile, no significant differences among the treatments were observed on intrinsic water use efficiency $\left(A / g_{s}\right)$ and $C_{i} / C_{a}$ ratio.

\section{Foliar biochemical components}

Leaf biochemical analysis is shown in Table 2. Relatively to SDIAF, FI treatment presented $39 \%$ and $32 \%$ higher concentrations of $\mathrm{Chl}_{(\mathrm{a}+\mathrm{b})}$ and Car, respectively. On the other hand, although no significant differences were recorded among the DIS treatments, RDI and SDI leaves presented similar concentrations of 
photosynthetic pigments as FI trees. Conversely, SDIAF leaves presented higher concentration of flavonoids and superior TAC than the other treatments. In addition, among the newly applied irrigation treatments, FI and RDI exhibited the lower investment in flavonoids and TAC. The higher concentration of TPC was recorded in SDIAF and SDI leaves, while the superior concentration of ODC was observed in RDI and SDI leaves. No significant differences among treatments were detected on $\mathrm{Chl}_{\mathrm{a}} / \mathrm{Chl}_{\mathrm{b}}$ and $\mathrm{Chl}_{(\mathrm{a}+\mathrm{b})} /$ Car ratios, as well on $\beta$-carotene, TSP, -SH, and SS concentrations.

\section{Crop yield and fruit physicochemical characteristics}

Crop yield increased with expanding seasonal water volume. Fruit yield was $2040 \mathrm{~kg} \mathrm{ha}^{-1}$ for FI control, $1789 \mathrm{~kg} \mathrm{ha}^{-1}$ for RDI, $1487 \mathrm{~kg} \mathrm{ha}^{-1}$ for SDI, and $933 \mathrm{~kg} \mathrm{ha}^{-1}$ for SDIAF, although only statistical significant differences were observed between FI and SDIAF treatments. However, when considering the yield per unit of water volume during the seasonal irrigation period (Water productivity $(\mathrm{WP})=$ yield $/$ unit of irrigation water used), a different behaviour was obtained, as SDI (142,98 $\left.\mathrm{kg} \mathrm{ha}^{-1} \mathrm{~mm}^{-1}\right)$ presented higher WP than FI (49.76 $\left.\mathrm{kg} \mathrm{ha}^{-1} \mathrm{~mm}^{-1}\right)$ and RDI $\left(78.81 \mathrm{~kg} \mathrm{ha}^{-1} \mathrm{~mm}^{-1}\right)$ (Table $3)$.

The maturation index (MI) of the fruits, as well their weight, dry matter, pulp/pit ratio, colour and peel break force analysis at harvest are also shown in Table 3 . The maturation index among treatments varied in the order $\mathrm{SDI}>\mathrm{FI}>\mathrm{RDI}=\mathrm{SDIAF}$. Moreover, FI treatment presented higher fruit weight than the SDIAF regime, while no differences were recorded among the DIS treatments. By other side, fruit dry matter was lower in FI treatment than in the DIS treatments. All the newly applied irrigation regimes had inferior pulp/pit ratio than SDIAF treatment. For colour measurements, 
only chroma (C) showed significant differences, with lower values in FI than in SDIAF fruits. Furthermore, fruits of all DIS treatments studied presented higher peel break than FI fruits.

The concentrations of fruit phenolic compounds, namely TPC, ODC and FL, and TAC responded differently to the different irrigation treatments and harvest dates (Table 4). In all samplings, SDIAF treatment consistently showed a general trend for higher concentrations of phenolic compounds, TPC, ODC and FL, as well as TAC in the fruits, except on the last sampling date, where SDI fruits exhibited higher TAC. In relation to SDIAF treatment, on September $19^{\text {th }}$, RDI and SDI reduced the concentrations of TPC, FI, RDI and SDI treatments reduced the concentrations of ODC, while a difference in FL concentration was only recorded between FI and SDI, higher in the last treatment. Relatively to SDIAF, FI and RDI treatments reduced TAC in $62 \%$ and $41 \%$, respectively, while no significant differences were detected relatively to SDI. Meanwhile, on October $11^{\text {th }}$, relatively to SDIAF, FI reduced the concentrations of TPC and FL, and FI and RDI reduced the concentrations of ODC and TAC. In relation to SDIAF, on October $25^{\text {th }}$, FI, RDI and SDI treatments reduced the concentrations of TPC and FL, FI reduced the concentration of ODC, while SDI increased TAC. In general, between September $19^{\text {th }}$ and October $11^{\text {th }}$ was observed a reduction in the concentrations of TPC and FL, which increased again on October $25^{\text {th }}$. By other side, a general increment in ODC concentrations was observed along the sampling dates. In DIS treatments, the TAC response along the sampling dates followed the TPC and FL pattern, while increased progressively in FI treatment.

Regarding the fat content (Table 4), on September $19^{\text {th }}$ no significant differences among treatments were recorded. On October $11^{\text {th }}$, when expressed by FW, higher fat content was observed in SDI, while on the last harvest, FI fruits showed a lower fat 
content (both expressed by DW and FW) than all DIS treatments. The fat content highly increased from September $19^{\text {th }}$ to October $11^{\text {th }}$, and stabilized, or even declined to October $25^{\text {th }}$.

Table 5 shows the influence of water regimes on the phenolic profile of olive fruits at three harvest dates. The evolution of the phenolic compounds concentrations along the sampling dates was dependent on both phenolic compound type and irrigation regime. A general increase along the sampling dates was recorded for hydroxytyrosol, oleuropein, caffeic acid, apigenin-7-O-glucoside and quercetin-3-O-glucoside. The exceptions were observed for oleuropein and apigenin-7-O-glucoside in SDIAF treatment, that presented reductions from the $1^{\text {st }}$ to the other sampling dates, and from the $2^{\text {nd }}$ to the $3^{\text {rd }}$ sampling date, respectively. The increase from the $1^{\text {st }}$ to the $2^{\text {nd }}$ date, with a subsequent decline to the $3^{\text {rd }}$ sampling date was observed for chlorogenic acid, kaempferol-3-O-glucoside, luteolin-7-O-glucoside and rutin.

The irrigation regime changed the concentration of some phenolic compounds in each sampling date. No special differences among treatments were recorded for hydroxytyrosol, except on September $19^{\text {th }}$, in which the concentration was higher in FI than in RDI treatment. By other side, in relation to SDIAF, oleuropein concentration was reduced by the newly applied irrigation regimes on September $19^{\text {th }}$, while on October $25^{\text {th }}$ RDI had higher concentration than SDIAF. Chlorogenic acid concentration was only affected by the water regime on October $11^{\text {th }}$, where SDI showed lower concentration than SDIAF. Moreover, no consistent trend was observed on caffeic acid concentration. On the $1^{\text {st }}$ harvest no significant differences among treatments were recorded, while on October $11^{\text {th }}$ FI fruits had higher concentration than SDIAF, and in the last sampling date RDI fruits presented higher concentration than SDI. Among flavonoids, only apigenin-7-O-glucoside, kaempferol-3-O-glucoside and 
quercetin-3,7'-di-O-glucoside concentrations were significantly affected by the irrigation treatments. On September $19^{\text {th }}$, FI had higher concentration of apigenin-7-Oglucoside than SDIAF, while no differences were recorded among the DIS regimes. On October $11^{\text {th }}$ this pattern was reversed, as FI and RDI treatments showed lower concentrations than SDIAF, while on October $25^{\text {th }}$ all the newly applied irrigation regimes had superior apigenin-7-O-glucoside concentration than SDIAF. Kaempferol3-O-glucoside was only significantly affected by the irrigation regime on the $1^{\text {st }}$ and $2^{\text {nd }}$ sampling dates. On September $19^{\text {th }}$, FI and RDI had higher concentrations than SDIAF, while on October $11^{\text {th }}$, FI fruits presented a reversed pattern. Furthermore, the significant differences recorded on quercetin-3,7'-di-O-glucoside was only recorded on the $1^{\text {st }}$ harvest, where FI fruits showed lower concentration than all the DIS treatments.

The irrigation regimes influenced, to some extent, the fatty acids profile on the $3^{\text {rd }}$ harvest, although the two major fatty acids (oleic acid and palmitic acid) were not affected, as shown in Table 6. Significant differences were observed for palmitoleic (C16:1), linoleic (C18:2), and linolenic (C18:3) acids. Relatively to SDIAF treatment, FI regime had higher levels (30\%) of palmitoleic acid (C16:1), while FI, RDI and SDI treatments presented 16\%, 9\% and 21\% higher levels of linoleic acid (C18:2). Conversely, RDI and SDI exhibited $31 \%$ and $28 \%$ lower levels of linolenic acid (C18:3) than SDIAF.

\section{DISCUSSION}

\section{Leaf water status, sclerophylly and gas exchange}

Olive trees subjected to the newly applied irrigation regimes (FI, RDI and SDI) exhibited, in general, a better water status than plants under the SDIAF regime. Among 
the DIS treatments, stood out RDI plants that displayed the capacity to continuously maintain leaf water status similar to FI plants (Figure 1), as a result of the higher water supply through the summer season, $102 \%$ and $162 \%$ more than SDI and SDIAF, respectively, still only $56 \%$ of FI (Table 1). Remarkably, this capacity is preserved even when only $10 \%$ of $\mathrm{ET}_{\mathrm{c}}$ was applied, confirming that during the pit hardening stage olive tree is less sensitive to water deficit. ${ }^{51}$ Our observation of lower RWC in sustained deficit irrigation strategies, especially in SDIAF treatment with only $21.2 \%$ of $\mathrm{ET}_{\mathrm{c}}$ applied, is in accordance with previous studies. ${ }^{20,51,52}$ On the other hand, the absence of significant differences in leaf RWC among treatments at the beginning of August and mid-September, which were even slightly better than in previous measures, is a response to earlier precipitation events (Table 1), confirming the quick recovery of water status by olive tree. ${ }^{53}$ Meanwhile, the expected higher leaf density in DIS treatments by the end of the summer shows the primary role that water availability plays in modifying leaf structure. Higher leaf tissue density can result from reductions in turgor pressure and cell expansion, resulting in the same dry mass within a smaller leaf area. ${ }^{4,54}$ Leaves with high tissue density are able to better survive to severe drought events due to higher resistance to desiccation damage and are also mechanically more stable, resulting in longer life-span. ${ }^{4,54}$

The enhanced $\mathrm{A}$ and $\mathrm{g}_{\mathrm{s}}$ of plants subjected to the newly applied irrigation treatments relatively to SDIAF, comes in line with the higher water supply and the better water status of trees. The closely association between $A$ and $g_{s}$, as verified by Tekaya et. al. ${ }^{9}$ suggests that the decline in net photosynthesis of SDIAF plants is largely a consequence of stomatal limitation. Nonetheless, as $\mathrm{C}_{\mathrm{i}} / \mathrm{C}_{\mathrm{a}}$ values did not follow the same trend, in spite of lower $\mathrm{g}_{\mathrm{s}}$, indicate that non-stomatal limitations to photosynthesis also occur. Similar results were reported previously in olive tree. ${ }^{3,53}$ Interestingly, 
although RDI and SDI regimes used substantial lower amounts of water in relation to FI, plants under those treatments maintained $\mathrm{A}$ and $\mathrm{g}_{\mathrm{s}}$ at FI levels, demonstrating the olive tree resilience to low/moderate water deficit, and that is possible to save water in this crop, which is economically and environmentally advantageous. Similarly, no significant differences of $\mathrm{A}$ and $\mathrm{g}_{\mathrm{s}}$ among RDI, SDI and FI treatments have been previously reported in olive trees under South Spain conditions. ${ }^{55}$

\section{Foliar biochemical components}

As net photosynthesis decreased under low-frequency deficit irrigation, an excess of reducing power is frequently generated and, thus, over-reduction of photosynthetic electron chain may result in the formation of reactive oxygen species that can cause oxidative damage. In fact, leaves from this treatment revealed signs of oxidative stress, as confirmed by the lower concentrations of $\mathrm{Chl}_{(\mathrm{a}+\mathrm{b})}$ and Car relatively to FI plants. Nevertheless, the degradation of the photosynthetic machinery may also be seen as a mean to mobilise resources for the production of new acclimated leaves and to avoid excessive energy absorption, ${ }^{56}$ in order to reduce photoinhibitory damages.

Interestingly, SDIAF plants were able to maintain a similar amount of leaf soluble sugars as in FI trees, in spite of the lower net photosynthesis. This may be linked to a lower sink demand and also in order to perform osmotic adjustment, as observed in potted olive trees. ${ }^{4}$ In the same way, no significant differences in the concentration of total soluble proteins were observed among treatments. As in other studies with the same olive cultivar were reported decreases or increases on $\mathrm{TSP}^{4,},{ }^{43}$ we may infer that differences on the imposition mode, duration and severity of water stress, as well environmental conditions, explain the balance between protein synthesis and their degradation. On the other hand, plants under water deficit need to invest in 
secondary metabolism, e.g. production of phenolic compounds, like polyphenols, that possess ideal chemistry for free radical scavenging, overcoming other antioxidants in the capacity to donate electrons or hydrogen atoms. ${ }^{4,} 57$ Although both SDI and SDIAF exhibited higher TPC concentrations, only SDIAF showed higher TAC, certainly in association with the increase in flavonoids concentration (25\%). In line, the accumulation of phenolic compounds in olive leaves in response to water deficit conditions was previously reported. ${ }^{4,9,58}$

\section{Yield and fruit physicochemical characteristics}

In spite of the contribution of the higher net photosynthetic rate of FI, RDI and SDI plants for the higher productivity, the increase of crop yield, relatively to SDIAF, was correlated with the seasonal water volume, in line with previous studies. ${ }^{22,30,59}$ Meanwhile, the higher crop yield of FI trees in relation to DIS treatments was associated with the higher weight of the fruits. However, the higher fruit weight was more evident when expressed by fresh weight than by dry weight, meaning that the water content on fruits is decisive on crop yield measurements. By other side, the increase in water productivity in DIS treatments, despite the crop yield reduction, means that DIS regimes can be an important tool for farmers to increase production, reduce costs, and developing a sustainable agricultural activity. ${ }^{11,60}$ Relatively to SDIAF, SDI appears to have a better balance on crop yield and water productivity than RDI. Although RDI showed an increase of $91 \%$ in crop yield and SDI an increase of $59 \%$, RDI presented a reduction of $26 \%$ in water productivity, while SDI exhibited an increase of $33 \%$.

The analysis of chroma suggest that olives colour intensity increases slightly with reduced water availability. In fact, it is common to find in other studies that 
reduced water availability accelerates the ripening process. ${ }^{50,61}$ However, this was not clear in the maturation index, probably due to the early stage of fruit development during our sampling dates, between September and October. Meanwhile, the higher maximum force $(\mathrm{N})$ reached during the puncturing test in all the DIS treatments (Table 3) might be related to the increased firmness of the fruits and the overall lower water content/higher fruit dry matter (Table 3$){ }^{45,62}$

The TPC, ODC and FL concentrations, and TAC were measured on the olive flesh from FI and DIS treatments during three harvest dates in order to understand the influence of the irrigation regimes on the polyphenol's concentrations and antioxidant activity of olives. Moreover, these results are expressed on a dry weight (DW) basis to eliminate variations in water content between sampling dates and irrigation treatments. The overall decrease in TPC and FL values from the $1^{\text {st }}$ to the $2^{\text {nd }}$ harvest might be a response to a rainfall event, which was accompanied by a rapid increase in fruit weight. In fact, from the $2^{\text {nd }}$ to the $3^{\text {rd }}$ harvest TPC and FL concentrations increased again, and ODC continuously increased through the sampling dates. As expected, in general, the TAC of fruits followed the phenolic compounds accumulation, as described in other studies. ${ }^{63,64}$ Although it is usual to find a decrease in the concentration of phenolic compounds during the ripening process,${ }^{50}$ it should be noted that in the present study the first two harvests were performed very early in the fruit development process, where the accumulation of phenolic compounds still occurs. Hence, it would be expected that phenolic compounds and TAC values start to decrease after the last harvest. ${ }^{50}$ Taking into account the climatic conditions of the Trás-os-Montes region, which is characterized by long cold winters, the commercial harvest date, made before full ripening, usually revolves around the end of November and December. However, the farmer where the field trial was located performs the harvest during an early ripening 
stage (mid to end of October), in order to produce an exquisite extra virgin olive oil, known by the high-quality with a low acidity.

As expected, the increase in water supply reduces the accumulation of phenolic compounds in fruits. By other side, the decrease in water supply increased the stressful conditions experienced by the plants, as observed by the physiological performance of the trees and, consequently, the necessity to invest in the secondary metabolism to protect against oxidative stress. ${ }^{53}$ In fact, several studies reported that stressful conditions increase the accumulation of phenolic compounds in olive fruits. ${ }^{9,} 22,50,65,66$ Although the increased accumulation of phenolic compounds improve its antioxidant properties, oils are occasionally characterized as excessively bitter. ${ }^{67}$ Moreover, the increase in quality conferred by the phenolic compounds, usually is not compensated by the losses in yield, as observed in SDIAF treatment. In this context, SDI appears to have a great balance, not only with crop load and water productivity but also with phenolic compounds accumulation. In line, deficit irrigation strategies have been pointed a good option to compensate the losses in quantity maintaining the products quality. ${ }^{67,} 68$ Interestingly, during the final harvest, though the SDI treatment presented lower TPC and FL concentrations than SDIAF, it showed higher TAC values, probably because other compounds with important antioxidant capacity are present in these olive fruits, as in other studies. ${ }^{64}$ The lack of correlation between phenolics and TAC was already reported by Brito et al. ${ }^{65}$

The type and the quantity of polyphenols in olive fruits fluctuate depending upon on the development and growing conditions, the cultivar and the stage of ripening. ${ }^{10,50}$ In order to understand the changes observed in the phenolic profile during maturation of cv. Cobrançosa, and among the different irrigation treatments, we analysed them by RP-HPLC-DAD, reference compounds were used as standards and 
the presence or absence of a particular polyphenolic compound was assessed by comparison of the retention time and UV-vis spectra. ${ }^{50,69}$ The majority of fruit samples presented the same chemical profile, composed of 10 identified phenolic compounds: hydroxytyrosol, oleuropein, chlorogenic acid, caffeic acid, apigenin-7-glucoside, kaempferol-3-O-glucoside, luteolin-7-O-glucoside, quercetin-3-O-glucoside, quercetin3,7'-di-O-glucoside, and rutin (Table 5). The SDIAF treatment presented higher oleuropein content than the other treatments in the first harvest. The amount of oleuropein range considerable during the 3 harvest dates, increasing significantly. Oleuropein is generally considered a major precursor of olive phenolic compounds. It is well described that the accumulation of oleuropein occurs during the fruit growth phase where it can reach as far as $14 \%$ of dry matter. On the other hand, through the process of maturation and late harvesting, usually very low levels of oleuropein are found. ${ }^{70}$ The increased values detected during the 3 harvest dates is in accordance with the aforementioned increasing levels of ODC and TAC concentrations, which relates to the very early commercial harvest dates of this farmer. Thus, our results demonstrated the relevance of an early harvest in order to obtain higher oleuropein levels and, thus, higher health benefits.

Hydroxytyrosol is considered the most powerful antioxidant compound after gallic acid and one of the most powerful antioxidant compounds between phenolic compounds from olive tree products and, thus, its regular consumption has several beneficial effects such as antioxidant, anti-inflammatory, anticancer, and as a protector of skin and eyes. ${ }^{71}$ Interestingly, at the final harvest, hydroxytyrosol was only detected in SDI treatment. Derived from hydrolysis of the polyphenol oleuropein, hydroxytyrosol has been shown to increase as the fruit ripening occurs. ${ }^{66}$ As mentioned 
for the oleuropein concentration in our study, the early commercial harvesting can explain our results.

First reported to occur only in leaves of Olea europaea, chlorogenic acid has been recurrently described in olives. ${ }^{69}$ Besides the higher chlorogenic acid concentration of the SDIAF treatment, at the last harvest date it is important to note the higher values found in our study, ranging from 55.1 to $531.0 \mathrm{mg} \mathrm{kg}^{-1}$ compared to those found previously in Cobrançosa and other Portuguese olive cultivars, generally under $12.5 \mathrm{mg}$ $\mathrm{Kg}^{-1} 69$

While no differences between DIS treatments and FI control could be observed for quercetin-3-O-glucoside, is was interesting to detect a higher quercetin-3,7'-di-Oglucoside concentration in the $1^{\text {st }}$ harvest date for the DIS treatments. In our study DIS treatments appear to increase the concentration of this quercetin derivative in olive fruit of this particular cultivar. Previously described in onions, changes in the quercetin derivatives content might influence not only the TAC of the fruit extract but also their biological activity and human health inherit benefits. ${ }^{72}$

Rutin was the predominant flavonoid, which was expected since it is reported to occur in olive fruits, even when other compounds are not present. ${ }^{66,}{ }^{69}$ Still, no differences in rutin concentration was observed. Besides, the aforementioned components, other flavonoids were detected, such as apigenin, kaempferol, and luteolin, which shows the diversity and fluctuation that these constituents suffer during the fruit development/ripening, and the different irrigation regimes. The increased concentration of oleuropein, kaempferol-3-O-glucoside, and quercetin-3,7'-di-O-glucoside in DIS treated plants, even if due to the early ripening stage, can influence the biological activity and human health inherit benefits associated with the consumption of the fruits and olive oil, therefore it justifies further studies. ${ }^{72}$ 
The fruit fat content was affected by the irrigation strategies applied, and a higher accumulation was observed in the DIS treatments compared to FI control, reaching $29 \%$ in SDI. And while it is well established that the process of oil accumulation on olives is subtle to water deficit, ${ }^{73}$ it is important to point out the very early harvest dates pursued in this study, consequently oil accumulation might not had yet reached its maximum. ${ }^{5}$ It is described that oil content is related with the amount of mesocarp available for oil biosynthesis. ${ }^{73}$ SDIAF had fruits with the highest pulp/pit ratio (Table 3) which translated into fruits with the highest fat content when expressed as $\%$ of $\mathrm{FW}$, both in the $2^{\text {nd }}$ and $3^{\text {rd }}$ harvest dates.

In general, no major differences were observed for the majority of the fatty acid's contents, still small decreases in palmitoleic acid (C16:1), linoleic acid (18:2) and linolenic acid (18:3) contents were observed in the DIS treatments. However, these differences did not reflect changes in MUFA or PUFA content and in the unsaturated/saturated fatty acid, C18:1/C18:2 and MUFA/PUFA ratios. Previous studies have been producing divergent results, as both increase and decrease in irrigation can lead to PUFA content to increase. ${ }^{23}$ It has also been shown that different irrigation strategies has only minor effects on the unsaturated/saturated fatty acid and MUFA/PUFA ratios. ${ }^{11}$ Furthermore, as C18:1/C18:2 and MUFA/PUFA ratios are closely associated with stability ${ }^{9}$, our results indicate that oils from these treatments may have similar oxidative stability. Ultimately, the most common findings in the available literature is in severe water deficit scenarios, with absence of irrigation, which affects the oil fatty acid composition. ${ }^{10}$ 


\section{CONCLUSIONS}

The newly applied irrigation systems (FI, RDI and SDI) improved plant performance in relation to the system adopted by the farmer (SDIAF), including water status and net photosynthetic rate. By the end of the summer season, the leaves from all DIS treatments developed higher tissue density and, in general, presented changes in secondary metabolism, with higher accumulation of phenolic compounds, responses that boost drought resistance.

Although the newly applied irrigation systems improved crop yield in parallel with the volume of water applied, the water productivity tends to decrease. An increment in fruits phenolic compounds accumulation and antioxidant capacity was also observed with the reduction of water supply. Overall, SDI appears to have a great balance between crop load, water productivity and the accumulation of phenolic compounds in fruits. Interestingly, the oil accumulation was higher in DIS treatments than in FI system. Furthermore, no impacting changes into the phenolic and fatty acids composition were observed.

The results of this study allow to conclude that deficit irrigation strategies are essential for sustainable olive growing in regions of limited water resources. It was also observed that commercial harvest dates very early in the ripening process changes fruit quality parameters, specifically the phenolic and fatty acid composition, which can then have effects into the olive oil quality and their associated health benefits. Hence, further studies into different deficit irrigation strategies combined with the effects on the quality parameters during different phases of the ripening process are needed for $\mathrm{cv}$. "Cobrançosa" and other important cultivars, in order to optimize the adoption of efficient irrigation strategies adjusted to the evolving commercial practices in place. 


\section{ACKNOWLEDGEMENTS}

This work was funded by the INTERACT project - "Integrative Research in Environment, Agro-Chains and Technology", no. NORTE-01-0145-FEDER-000017, in its line of research entitled ISAC, co-financed by the European Regional Development Fund (ERDF) through NORTE 2020 (North Regional Operational Program 2014/2020); and supported by the institution CITAB with the financial support through the European Investment Funds by FEDER/COMPETE/POCI-Operational Competitiveness and Internationalization Program, under Project POCI-01-0145-FEDER-006958 and National Funds by FCT - Portuguese Foundation for Science and Technology, under the project UID/AGR/04033/2019

\section{CONFLICTS OF INTEREST}

The authors declare no conflicts of interest.

\section{AUTHORS' CONTRIBUTION}

J. Moutinho-Pereira and C. Correia planned the experiments with the help of A. Gonçalves. E. Silva, S. Martins, L. Pinto, C. Martins-Gomes, L. Dinis and A. Luzio performed all the experiments with the help of A. Gonçalves, F. Nunes, C. Ribeiro, A. Rodrigues and A. Fernandes-Silva. A. Gonçalves and C. Brito analysed the results and wrote the manuscript with the help of C. Correia. 


\section{REFERENCES}

1. Cramer W, Guiot J, Fader M, Garrabou J, Gattuso J-P, Iglesias A, Lange MA, Lionello P, Llasat MC, Paz S, Peñuelas J, Snoussi M, Toreti A, Tsimplis MN and Xoplaki E, Climate change and interconnected risks to sustainable development in the Mediterranean. Nature Climate Change (2018).

2. Ponti L, Gutierrez AP, Ruti PM and Dell'Aquila A, Fine-scale ecological and economic assessment of climate change on olive in the Mediterranean Basin reveals winners and losers. Proceedings of the National Academy of Sciences of the United States of America 111:55985603 (2014).

3. Bacelar EA, Moutinho-Pereira JM, Goncalves BC, Ferreira HF and Correia CA, Changes in growth, gas exchange, xylem hydraulic properties and water use efficiency of three olive cultivars under contrasting water availability regimes. Environ Exp Bot 60:183-192 (2007).

4. Bacelar EA, Santos DL, Moutinho-Pereira JM, Goncalves BC, Ferreira HF and Correia $\mathrm{CM}$, Immediate responses and adaptative strategies of three olive cultivars under contrasting water availability regimes: Changes on structure and chemical composition of foliage and oxidative damage. Plant Sci 170:596-605 (2006).

5. Fernandes-Silva AA, Ferreira TC, Correia CM, Malheiro AC and Villalobos FJ, Influence of different irrigation regimes on crop yield and water use efficiency of olive. Plant Soil 333:3547 (2010).

6. Brito $\mathrm{C}$, Dinis LT, Ferreira H, Moutinho-Pereira J and Correia $\mathrm{C}$, The role of nighttime water balance on Olea europaea plants subjected to contrasting water regimes. J Plant Physiol 226:56-63 (2018).

7. Brito C, Dinis LT, Meijon M, Ferreira H, Pinto G, Moutinho-Pereira J and Correia C, Salicylic acid modulates olive tree physiological and growth responses to drought and rewatering events in a dose dependent manner. J Plant Physiol 230:21-32 (2018).

8. Ramos AF and Santos FL, Yield and olive oil characteristics of a low-density orchard (cv. Cordovil) subjected to different irrigation regimes. Agr Water Manage 97:363-373 (2010).

9. Tekaya M, Mechri B, Dabbaghi O, Mahjoub Z, Laamari S, Chihaoui B, Boujnah D, Hammami $\mathrm{M}$ and Chehab $\mathrm{H}$, Changes in key photosynthetic parameters of olive trees following soil tillage and wastewater irrigation, modified olive oil quality. Agr Water Manage 178:180188 (2016).

10. Tovar MJ, Romero MP, Girona J and Motilva MJ, L-phenylalanine ammonia-lyase activity and concentration of phenolics in developing olive (Olea europaea $\mathrm{L} \mathrm{cv}$ Arbequina) fruit grown under different irrigation regimes. Journal of the science of food and agriculture 82:892898 (2002).

11. Tognetti $R$, d'Andria $R$, Lavini $A$ and Morelli $G$, The effect of deficit irrigation on crop yield and vegetative development of Olea europaea L. (cvs. Frantoio and Leccino). Eur J Agron 25:356-364 (2006).

12. Marsal J, Mata M, Arbones A, Rufat J and Girona J, Regulated deficit irrigation and rectification of irrigation scheduling in young pear trees: an evaluation based on vegetative and productive response. Eur J Agron 17:111-122 (2002).

13. Marsal J, Lopez G, Mata M and Girona J, Postharvest deficit irrigation in 'Conference' pear: Effects on subsequent yield and fruit quality. Agr Water Manage 103:1-7 (2012).

14. Chaves MM, Santos TP, Souza CR, Ortuno MF, Rodrigues ML, Lopes CM, Maroco JP and Pereira JS, Deficit irrigation in grapevine improves water-use efficiency while controlling vigour and production quality. Ann Appl Biol 150:237-252 (2007).

15. Goldhamer DA, Salinas M, Crisosto C, Day KR, Soler M and Moriana A, Effects of regulated deficit irrigation and partial root zone drying on late harvest peach tree performance. Acta Hortic:343-350 (2002).

16. Leib BG, Caspari HW, Redulla CA, Andrews PK and Jabro JJ, Partial rootzone drying and deficit irrigation of 'Fuji' apples in a semi-arid climate. Irrigation Sci 24:85-99 (2006). 
17. Fereres $\mathrm{E}$ and Soriano MA, Deficit irrigation for reducing agricultural water use. J Exp Bot 58:147-159 (2007).

18. Berenguer MJ, Vossen PM, Grattan SR, Connell JH and Polito VS, Tree irrigation levels for optimum chemical and sensory properties of olive oil. Hortscience 41:427-432 (2006).

19. Grattan SR, Berenquer MJ, Connell JH, Polito VS and Vossen PM, Olive oil production as influenced by different quantities of applied water. Agr Water Manage 85:133-140 (2006).

20. Iniesta F, Testi L, Orgaz F and Villalobos FJ, The effects of regulated and continuous deficit irrigation on the water use, growth and yield of olive trees. Eur J Agron 30:258-265 (2009).

21. del Campo MG and Garcia JM, Summer Deficit-Irrigation Strategies in a Hedgerow Olive cv. Arbequina Orchard: Effect on Oil Quality. J Agr Food Chem 61:8899-8905 (2013).

22. Tekaya M, Chehab H, Flamini G, Gharbi I, Mahjoub Z, Laamari S, Chihaoui B, Boujnah D, Hammami $M$ and Mechri B, Modification of pomological characteristics and flavour components of fruits and virgin olive oil following wastewater irrigation and soil tillage. Journal of the science of food and agriculture 98:2942-2952 (2018).

23. Garcia JM, Cuevas MV and Fernandez JE, Production and oil quality in 'Arbequina' olive (Olea europaea, L.) trees under two deficit irrigation strategies. Irrigation Sci 31:359-370 (2013).

24. WRB, World Reference Base for Soil Resources 2014. International soil classification system for naming soils and creating legends for soil maps. World Soil Resources Reports No. 106. FAO, Rome. (2014).

25. Bryson G, Mills HA, Sasseville DN, Jones Jr JB and Barker AV, Plant Analysis Handobook III. A Guide to Sampling, Preparation, Analysis and Interpretation for Agronomic and Horticultural Crops. Micro-Macro Publishing, Inc. Athens, GA. (2014).

26. Kottex $M$ and Grieser J, World Map of the Koppen-Geiger climate classification updated. Meteorologische Zeitschrif 15:269-263 (2006).

27. Doorenbos J and Pruit WO, Crop water requirements. FAO Irrigation and drainage paper. Seires number: 24. FAO, Rome (1977).

28. Fereres E, Pruit WO, Beutel JA, Henderson DW, Holzaptel E, Shulbach H and Uriu K, ET and drip irrigation scheduling. University of California, Division of Agricultural Science Davis, USA (1981).

29. Allen RG, Pereira LS, Raes D and Smith M, Crop evapotranspiration-guidelines

for computing crop water requirements. FAO, Roma, Italy (1998).

30. Fernandes-Silva A, Necessidades hídricas e resposta da oliveira (Olea europaea L.) ao deficit hídrico na região da terra quente, Ed. University of Trás-os-Montes and Alto Douro, Vila Real, Portugal (2008).

31. Orgaz F, Testi L, Villalobos FJ and Fereres E, Water requirements of olive orchards - II: determination of crop coefficients for irrigation scheduling. Irrigation Sci 24:77-84 (2006).

32. von Caemmerer $S$ and Farquhar GD, Some Relationships between the Biochemistry of Photosynthesis and the Gas-Exchange of Leaves. Planta 153:376-387 (1981).

33. Arnon DI, Copper Enzymes in Isolated Chloroplasts - Polyphenoloxidase in BetaVulgaris. Plant Physiol 24:1-15 (1949).

34. Lichtenthaler HK, Chlorophylls and Carotenoids - Pigments of Photosynthetic Biomembranes. Method Enzymol 148:350-382 (1987).

35. Sesták Z, Castky J and Jarvis PG, Plant photosynthetic production. Manual of methods. Dr. W. Junk Publs., The hagge. pp. 818. . (1971).

36. Barros L, Cabrita L, Boas MV, Carvalho AM and Ferreira ICFR, Chemical, biochemical and electrochemical assays to evaluate phytochemicals and antioxidant activity of wild plants. Food Chem 127:1600-1608 (2011).

37. Ellman GL, Tissue Sulfhydryl Groups. Arch Biochem Biophys 82:70-77 (1959). 
38. Singleton VL and J.A. R, Colorimetry of total phenolics with phosphomolybdicphosphotungstic acid reagents. American Journal of Enology and Viticulture 16:144-158 (1965). 39. Mateos R, Espartero JL, Trujillo M, Rios JJ, Leon-Camacho M, Alcudia F and Cert A, Determination of phenols, flavones, and lignans in virgin olive oils by solid-phase extraction and high-performance liquid chromatography with diode array ultraviolet detection. J Agr Food Chem 49:2185-2192 (2001).

40. Jia Z, Tang MC and Wu JM, The determination of flavonoid contents in mulberry and their scavenging effects on superoxide radicals. Food Chem 64:555-559 (1999).

41. Barros AIRNA, Nunes FM, Goncalves B, Bennett RN and Silva AP, Effect of cooking on total vitamin $C$ contents and antioxidant activity of sweet chestnuts (Castanea sativa Mill.). Food Chem 128:165-172 (2011).

42. Irigoyen JJ, Emerich DW and Sanchezdiaz M, Water-Stress Induced Changes in Concentrations of Proline and Total Soluble Sugars in Nodulated Alfalfa (Medicago sativa) Plants. Physiol Plantarum 84:55-60 (1992).

43. Hermoso M, Uceda M, Garcia A, Morales B, Frias ML and Férnandez A, Elaboración de aceite de calidad (Série Apuntes 5/92). Sevilha: Consejería de Agricultura e Pesca. (1991).

44. Pathare PB, Opara UL and Al-Said FA, Colour Measurement and Analysis in Fresh and Processed Foods: A Review. Food Bioprocess Tech 6:36-60 (2013).

45. Fadda C, Del Caro A, Sanguinetti AM and Piga A, Texture and antioxidant evolution of naturally green table olives as affected by different sodium chloride brine concentrations. Second International Symposium on Chestnut:133-138 (1999).

47. Folch J, Lees M and Stanley GHS, A Simple Method for the Isolation and Purification of Total Lipides from Animal Tissues. J Biol Chem 226:497-509 (1957).

48. Hartman L and Lago RC, Rapid preparation of fatty acid methyl esters from lipids. Laboratory practice 22:475-476 (1973).

49. Martins-Gomes C, Taghouti M, Schafer J, Bunzel M, Silva AM and Nunes FM, Chemical characterization and bioactive properties of decoctions and hydroethanolic extracts of Thymus carnosus Boiss. J Funct Foods 43:154-164 (2018).

50. Machado M, Felizardo C, Fernandes-Silva AA, Nunes FM and Barros A, Polyphenolic compounds, antioxidant activity and L-phenylalanine ammonia-lyase activity during ripening of olive cv. "Cobrancosa" under different irrigation regimes. Food Res Int 51:412-421 (2013).

51. Motilva MJ, Tovar MJ, Romero MP, Alegre S and Girona J, Influence of regulated deficit irrigation strategies applied to olive trees (Arbequina cultivar) on oil yield and oil composition during the fruit ripening period. Journal of the science of food and agriculture 80:2037-2043 (2000).

52. Molina-Alcaide $E$ and Yanez-Ruiz DR, Potential use of olive by-products in ruminant feeding: A review. Anim Feed Sci Tech 147:247-264 (2008).

53. Brito C, Dinis LT, Moutinho-Pereira J and Correia CM, Drought Stress Effects and Olive Tree Acclimation under a Changing Climate. Plants-Basel 8 (2019).

54. Niinemets $U$, Global-scale climatic controls of leaf dry mass per area, density, and thickness in trees and shrubs. Ecology 82:453-469 (2001).

55. Fernandez JE, Diaz-Espejo A, Infante JM, Duran P, Palomo MJ, Chamorro V, Giron IF and Villagarcia $L$, Water relations and gas exchange in olive trees under regulated deficit irrigation and partial rootzone drying. Plant Soil 284:273-291 (2006).

56. Correia C, Moutinho-Pereira J, Coutinho JF, Bjorn LO and Torres-Pereira JM, Ultraviolet-B radiation and nitrogen affect the photosynthesis of maize: a Mediterranean field study. Eur J Agron 22 (2005).

57. Blokhina $\mathrm{O}$, Virolainen $\mathrm{E}$ and Fagerstedt KV, Antioxidants, oxidative damage and oxygen deprivation stress: a review. Ann Bot-London 91:179-194 (2003).

58. Mattos LM and Moretti CL, Oxidative Stress in Plants Under Drought Conditions and the Role of Different Enzymes. Enzyme Engineering 5:136 (2015). 
59. Patumi M, d'Andria R, Marsilio V, Fontanazza G, Morelli G and Lanza B, Olive and olive oil quality after intensive monocone olive growing (Olea europaea L., cv. Kalamata) in different irrigation regimes. Food Chem 77:27-34 (2002).

60. Wahbi S, Wakrim R, Aganchich B, Tahi H and Serraj R, Effects of partial rootzone drying (PRD) on adult olive tree (Olea europaea) in field conditions under and climate - I. Physiological and agronomic responses. Agr Ecosyst Environ 106:289-301 (2005).

61. Zeleke KT and Ayton J, Fruit and oil quality of olive (Olea europaea L.) under different irrigation regimes and harvest times in south eastern Australia. Journal of Food Agriculture and Environment 12:458-464 (2014).

62. Tsantili E, Christopoulos MV, Pontikis CA, Kaltsikes P, Kallianou C and Komaitis M, Texture and other quality attributes in olives and leaf characteristics after preharvest calcium chloride sprays. Hortscience 43:1852-1856 (2008).

63. Gouvinhas I, Machado J, Gomes S, Lopes J, Martins-Lopes P and Barros AIRNA, Phenolic Composition and Antioxidant Activity of Monovarietal and Commercial Portuguese Olive Oils. $J$ Am Oil Chem Soc 91:1197-1203 (2014).

64. Sousa A, Malheiro R, Casal S, Bento A and Pereira JA, Antioxidant activity and phenolic composition of $\mathrm{Cv}$. Cobrancosa olives affected through the maturation process. $J$ Funct Foods 11:20-29 (2014).

65. Brito C, Dinis LT, Silva E, Goncalves A, Matos C, Rodrigues MA, Moutinho-Pereira J, Barros A and Correia C, Kaolin and salicylic acid foliar application modulate yield, quality and phytochemical composition of olive pulp and oil from rainfed trees. Sci Hortic-Amsterdam 237:176-183 (2018).

66. Gomez-Rico A, Fregapane $\mathrm{G}$ and Salvador MD, Effect of cultivar and ripening on minor components in Spanish olive fruits and their corresponding virgin olive oils. Food Res Int 41:433-440 (2008).

67. Servili $M$, Esposto $S$, Fabiani $R$, Urbani $S$, Taticchi $A$, Mariucci $F$, Selvaggini $R$ and Montedoro GF, Phenolic compounds in olive oil: Antioxidant, health and organoleptic activities according to their chemical structure. Inflammopharmacology 17:76-84 (2009).

68. Caruso G, Gucci R, Urbani S, Esposto S, Taticchi A, Di Maio I, Selvaggini R and Servili M, Effect of different irrigation volumes during fruit development on quality of virgin olive oil of cv. Frantoio. Agr Water Manage 134:94-103 (2014).

69. Vinha AF, Ferreres F, Silva BM, Valentao P, Goncalves A, Pereira JA, Oliveira MB, Seabra RM and Andrade PB, Phenolic profiles of Portuguese olive fruits (Olea europaea L.): Influences of cultivar and geographical origin. Food Chem 89:561-568 (2005).

70. Soler-Rivas C, Espin JC and Wichers HJ, Oleuropein and related compounds. Journal of the science of food and agriculture 80:1013-1023 (2000).

71. Martinez L, Ros $G$ and Nieto G, Hydroxytyrosol: Health Benefits and Use as Functional Ingredient in Meat. Medicines (Basel) 5 (2018).

72. Materska $M$, Quercetin and its derivatives: Chemical structure and bioactivity - A review. Pol J Food Nutr Sci 58:407-413 (2008).

73. Lavee $S$ and Wodner $M$, The effect of yield, harvest time and fruit size on the oil content in fruits of irrigated olive trees (Olea europaea), cvs. Barnea and Manzanillo. Sci HorticAmsterdam 99:267-277 (2004). 


\section{List of Figures:}

Figure 1. Evolution of leaf relative water content (RWC), in the left, and leaf density in irrigation treatments throughout the experiment, in the right. Different letters demonstrate significant differences $(\mathrm{P}<0.05)$ between treatments in each analyzed date. FI - fully irrigation, SDI - sustained deficit irrigation, RDI - regulated deficit and SDIAF - sustained deficit irrigation applied by the farmer.

Figure 2. Evolution of leaf gas exchange variables throughout the experiment. Net photosynthetic rate $(A)$, stomatal conductance $\left(g_{s}\right)$, intrinsic water use efficiency $\left(A / g_{s}\right)$ and ratio of intercellular to atmospheric $\mathrm{CO}_{2}$ concentration $\left(\mathrm{C}_{\mathrm{i}} / \mathrm{C}_{\mathrm{a}}\right)$. Different letters demonstrate significant differences $(\mathrm{P}<0.05)$ between treatments in each date. FI - fully irrigation, SDI - sustained deficit irrigation, RDI - regulated deficit and SDIAF sustained deficit irrigation applied by the farmer. 


\section{List of Tables}

Table 1. Mean values of global solar radiation (all period of 24 hours), minimum and maximum air temperature, rainfall and reference evapotranspiration (ETo) and amount of water by irrigation to control treatment, fully irrigated (FI) and three deficit irrigation treatments, regulated deficit irrigation (RDI), sustained irrigation (SDI) and sustained deficit irrigation applied by the farmer (SDIAF).

Table 2. Leaf biochemical analysis of fully irrigated (FI), regulated deficit irrigation (RDI), sustained irrigation (SDI) and sustained deficit irrigation applied by the farmer

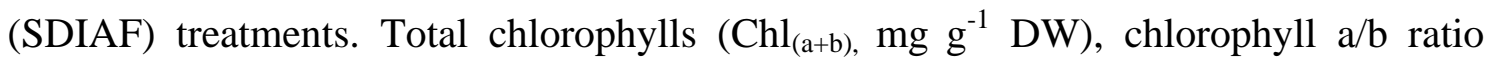
$\left(\mathrm{Chl}_{\mathrm{a}} / \mathrm{Chl}_{\mathrm{b}}\right)$, total carotenoids $\left(\mathrm{Car}, \mathrm{mg} \mathrm{g}^{-1} \mathrm{DW}\right), \mathrm{Chl}_{(\mathrm{a}+\mathrm{b})} /$ Car ratio, $\beta$-carotene $\left(\mathrm{mg} \mathrm{g}^{-1}\right.$ DW), total soluble proteins (TSP, $\mathrm{mg} \mathrm{g}^{-1} \mathrm{DW}$ ), total thiols (-SH, nmol mg ${ }^{-1} \mathrm{DW}$ ), total phenolic compounds (TPC, mg GAE g ${ }^{-1} \mathrm{DW}$ ), ortho-diphenols (ODC, mg GAE $\mathrm{g}^{-1}$ DW), flavonoids (mg CE g ${ }^{-1} \mathrm{DW}$ ) and soluble sugars concentrations (SS, $\mathrm{mg} \mathrm{g}^{-1} \mathrm{DW}$ ) and total antioxidant capacity (TAC, $\left.\mu \mathrm{mol} \mathrm{TE} \mathrm{g}^{-1} \mathrm{DW}\right)$.

Table 3. Fruit maturation index, yield, water productivity, fruit weight, colour and peel break force analysis of fully irrigated (FI), regulated deficit irrigation (RDI); sustained irrigation (SDI) and sustained deficit irrigation applied by the farmer (SDIAF) treatments during the final harvest.

Table 4. Olive fruit chemical characteristics of fully irrigated (FI), regulated deficit irrigation (RDI), sustained irrigation (SDI) and sustained deficit irrigation applied by the farmer (SDIAF) treatments during three harvest dates. Total phenolic compounds (TPC, mg GAE g ${ }^{-1} \mathrm{DW}$ ), ortho-diphenols content (ODC, mg GAE g ${ }^{-1} \mathrm{DW}$ ), flavonoids (mg CE g ${ }^{-1} \mathrm{DW}$ ), total antioxidant capacity (TAC, mmol TE kg${ }^{-1} \mathrm{DW}$ ), and fat content (\% of DW and \% of FW). 
Table 5. Olive fruit phenolic composition of fully irrigated (FI), regulated deficit irrigation (RDI), sustained irrigation (SDI) and sustained deficit irrigation applied by the farmer (SDIAF) treatments during three harvest dates $\left(\mathrm{mg} \mathrm{kg}^{-1} \mathrm{DW}\right)$.

Table 6. Olive fruit most representative fatty acids, and fatty acids saturated/unsaturated relations of fully irrigated (FI), regulated deficit irrigation (RDI), sustained irrigation (SDI) and sustained deficit irrigation applied by the farmer (SDIAF) treatments at final harvest. Saturated fatty acids (SFA), unsaturated fatty acids (UFA), monounsaturated fatty acids (MUFA), polyunsaturated fatty acids (PUFA).

Table 1. Mean values of global solar radiation (all period of 24 hours), minimum and maximum air temperature, rainfall and reference evapotranspiration $\left(\mathrm{ET}_{\mathrm{o}}\right)$ and amount of water by irrigation to control treatment, fully irrigated (FI) and three deficit irrigation treatments, regulated deficit irrigation (RDI), sustained irrigation (SDI) and sustained deficit irrigation applied by the farmer (SDIAF).

\begin{tabular}{cccccccccc}
\hline Period & $\begin{array}{c}\text { Solar } \\
\text { radiation } \\
\left(\mathbf{W m}^{-2}\right)\end{array}$ & $\begin{array}{c}\text { Temp } \\
\text { Min } \\
\left({ }^{\mathbf{0}} \mathbf{C}\right)\end{array}$ & $\begin{array}{c}\text { Temp } \\
\mathbf{M a x} \\
\left({ }^{\mathbf{0}} \mathbf{C}\right)\end{array}$ & $\begin{array}{c}\text { Rainfall } \\
(\mathbf{m m})\end{array}$ & $\begin{array}{c}\text { ETo } \\
(\mathbf{m m}\end{array}$ & \multicolumn{3}{c}{ Irrigation $(\mathbf{m m})$} \\
$\left.\mathbf{d}^{\mathbf{- 1}}\right)$ & FI & RDI & SDI & SDIAF \\
\hline $01-30 / 06 / 2016$ & 304 & 14.3 & 27.8 & 29.4 & 4.0 & 0 & 0 & 0 & 0 \\
$01-14 / 07 / 2016$ & 295 & 17.0 & 31.7 & 10.2 & 4.3 & 0 & 0 & 0 & 0 \\
$15-31 / 07 / 2016$ & 313 & 19.3 & 35.0 & 0 & 5.0 & 11.4 & 9.1 & 3.4 & 2.5 \\
$01-31 / 08 / 2016$ & 272 & 18.1 & 33.5 & 20.2 & 4.2 & 16 & 2.8 & 4.5 & 2.5 \\
$01-30 / 09 / 2016$ & 214 & 15.4 & 29.0 & 45.4 & 3.1 & 11.6 & 9.2 & 2 & 2.5 \\
$01-07 / 10 / 2016$ & 184 & 11.4 & 25.4 & 0 & 2.2 & 2 & 1.6 & 0.5 & 1.2 \\
$08-31 / 10 / 2016$ & 107 & 12.0 & 20.3 & 0.1 & 1.24 & 0 & 0 & 0 & 0 \\
Total & - & - & - & $\mathbf{1 0 5 . 3}$ & - & $\mathbf{4 1}$ & $\mathbf{2 2 . 8}$ & $\mathbf{1 1 . 3}$ & $\mathbf{8 . 7}$ \\
\hline
\end{tabular}

Table 2. Leaf biochemical analysis of fully irrigated (FI), regulated deficit irrigation (RDI), sustained irrigation (SDI) and sustained deficit irrigation applied by the farmer (SDIAF) treatments. Total chlorophylls $\left(\mathrm{Chl}_{(\mathrm{a}+\mathrm{b})}, \mathrm{mg} \mathrm{g}^{-1} \mathrm{DW}\right)$, chlorophyll $\mathrm{a} / \mathrm{b}$ ratio $\left(\mathrm{Chl}_{\mathrm{a}} / \mathrm{Chl}_{\mathrm{b}}\right)$, total carotenoids $\left(\mathrm{Car}, \mathrm{mg} \mathrm{g}^{-1} \mathrm{DW}\right), \mathrm{Chl}_{(\mathrm{a}+\mathrm{b})} / \mathrm{Car}$ ratio, $\beta$-carotene $\left(\mathrm{mg} \mathrm{g}^{-1}\right.$ $\mathrm{DW}$ ), total soluble proteins (TSP, $\left.\mathrm{mg} \mathrm{g}^{-1} \mathrm{DW}\right)$, total thiols (-SH, nmol $\mathrm{mg}^{-1} \mathrm{DW}$ ), total phenolic compounds (TPC, mg GAE g ${ }^{-1} \mathrm{DW}$ ), ortho-diphenols (ODC, mg GAE g ${ }^{-1}$ $\mathrm{DW}$ ), flavonoids (mg CE g ${ }^{-1} \mathrm{DW}$ ) and soluble sugars concentrations ( $\mathrm{SS}, \mathrm{mg} \mathrm{g}^{-1} \mathrm{DW}$ ) and total antioxidant capacity (TAC, $\mu \mathrm{mol} \mathrm{TE} \mathrm{g}^{-1} \mathrm{DW}$ ). 
Different letters within a line demonstrate significant differences $(\mathrm{P}<0.05)$ between treatments.

\begin{tabular}{lccccc}
\hline & FI & RDI & SDI & SDIAF & $\begin{array}{c}\text { P-value } \\
(\mathbf{P}<\mathbf{0 . 0 5})\end{array}$ \\
\hline Chl $_{(\mathbf{a}+\mathbf{b})}$ & $3.13^{\mathrm{a}}$ & $2.73^{\mathrm{a}, \mathrm{b}}$ & $2.61^{\mathrm{a}, \mathrm{b}}$ & $2.25^{\mathrm{b}}$ & $\mathbf{0 . 0 3 3 2}$ \\
Chl $_{\mathbf{a}} / \mathbf{C h l}_{\mathbf{b}}$ & 2.47 & 2.49 & 2.54 & 2.56 & 0.8469 \\
Car & $0.664^{\mathrm{a}}$ & $0.573^{\mathrm{a}, \mathrm{b}}$ & $0.608^{\mathrm{a}, \mathrm{b}}$ & $0.503^{\mathrm{b}}$ & $\mathbf{0 . 0 3 4 1}$ \\
Chl $_{(\mathbf{a}+\mathbf{b})} / \mathbf{C a r}$ & 4.71 & 4.76 & 4.28 & 4.48 & 0.1749 \\
$\boldsymbol{\beta - C a r o t e n e}$ & 0.177 & 0.158 & 0.151 & 0.142 & 0.0924 \\
TSP & 2.93 & 2.46 & 2.52 & 2.94 & 0.6121 \\
$\mathbf{- S H}^{\text {TPC }}$ & 0.662 & 0.667 & 0.652 & 0.805 & 0.5022 \\
ODC & $10.7^{\mathrm{b}}$ & $11.0^{\mathrm{b}}$ & $12.9^{\mathrm{a}}$ & $13.5^{\mathrm{a}}$ & $\mathbf{0 . 0 0 0 4}$ \\
Flavonoids & $12.9^{\mathrm{c}}$ & $84.2^{\mathrm{a}, \mathrm{b}}$ & $86.7^{\mathrm{a}}$ & $79.5^{\mathrm{b}, \mathrm{c}}$ & $<\mathbf{0 . 0 0 1}$ \\
SS & $92.9^{\mathrm{b}, \mathrm{c}}$ & $12.8^{\mathrm{c}}$ & $18.0^{\mathrm{b}}$ & $22.5^{\mathrm{a}}$ & $<\mathbf{0 . 0 0 1}$ \\
TAC & $83.9^{\mathrm{b}, \mathrm{c}}$ & $73.0^{\mathrm{c}}$ & $92.0^{\mathrm{b}}$ & $116.2^{\mathrm{a}}$ & $<\mathbf{0 . 0 0 1}$ \\
\hline
\end{tabular}

Table 3. Fruit maturation index, yield, water productivity, fruit weight, colour and peel break force analysis of fully irrigated (FI), regulated deficit irrigation (RDI); sustained irrigation (SDI) and sustained deficit irrigation applied by the farmer (SDIAF) treatments during the final harvest.

\begin{tabular}{|c|c|c|c|c|c|c|c|c|c|c|c|}
\hline & & Yiel & $\begin{array}{l}\text { Water } \\
\text { produc }\end{array}$ & $\begin{array}{c}\text { Fru } \\
\text { it }\end{array}$ & $\begin{array}{c}\text { Fru } \\
\text { it }\end{array}$ & Fru & Pulp & & Colour & & $\begin{array}{c}\text { Pee } \\
1\end{array}$ \\
\hline $\begin{array}{l}\text { Treat } \\
\text { ment }\end{array}$ & $\begin{array}{c}\text { Matur } \\
\text { ation } \\
\text { Index }\end{array}$ & $\begin{array}{c}\text { d } \\
(\mathbf{k g} \\
\mathbf{h a}^{-} \\
\mathbf{1})\end{array}$ & $\begin{array}{l}\text { tivity } \\
\left(\mathrm{kg} \mathrm{ha}^{-1}\right. \\
\left.\mathrm{mm}^{-1}\right)\end{array}$ & $\begin{array}{c}\text { wel } \\
\text { ght } \\
\text { (g, } \\
\text { FW } \\
\text { ) }\end{array}$ & $\begin{array}{c}\text { wel } \\
\text { ght } \\
\text { (g, } \\
\text { DW } \\
\text { ) }\end{array}$ & $\begin{array}{c}\text { dry } \\
\text { mat } \\
\text { ter } \\
(\%)\end{array}$ & $\begin{array}{c}\text { /PIt } \\
\text { ratio } \\
\text { (DW } \\
\text { ) }\end{array}$ & $\mathbf{L}$ & C & $\mathbf{h}^{\mathbf{o}}$ & $\begin{array}{c}\text { bre } \\
\text { ak } \\
\text { for } \\
\text { ce } \\
\text { (N) }\end{array}$ \\
\hline FI & 3.133 & $\begin{array}{c}204 \\
0^{\mathrm{a}}\end{array}$ & $49.8^{b}$ & $\underset{\mathrm{a}}{4.13}$ & $\underset{\mathrm{a}}{1.56}$ & $\begin{array}{c}37.9 \\
\mathrm{~b}\end{array}$ & ${ }_{, \mathrm{c}}^{1.52^{\mathrm{b}}}$ & $\begin{array}{c}30 . \\
56\end{array}$ & $\begin{array}{c}13.0 \\
5^{\mathrm{b}}\end{array}$ & $\begin{array}{l}24 . \\
61\end{array}$ & $\begin{array}{l}1.6 \\
8^{b}\end{array}$ \\
\hline
\end{tabular}




\begin{tabular}{|c|c|c|c|c|c|c|c|c|c|c|c|}
\hline RDI & 3.033 & $\begin{array}{c}178 \\
9^{\mathrm{a}}\end{array}$ & $78.8^{b}$ & $\begin{array}{c}3.49 \\
b\end{array}$ & $\underset{\mathrm{a}, \mathrm{b}}{1.48}$ & $\begin{array}{c}41.6 \\
\mathrm{a}\end{array}$ & $1.57^{\mathrm{b}}$ & $\begin{array}{l}31 . \\
75\end{array}$ & $\begin{array}{c}17.2 \\
2^{\mathrm{a}, \mathrm{b}}\end{array}$ & $\begin{array}{l}32 . \\
40\end{array}$ & $\begin{array}{c}4.7 \\
0^{\mathrm{a}}\end{array}$ \\
\hline SDI & 3.200 & $\begin{array}{l}148 \\
7^{\mathrm{a}, \mathrm{b}}\end{array}$ & $143.0^{\mathrm{a}}$ & $\underset{b}{3.25}$ & $\underset{\mathrm{b}}{1.32}$ & $\begin{array}{c}40.9 \\
\mathrm{a}\end{array}$ & $1.42^{\mathrm{c}}$ & $\begin{array}{c}32 . \\
00\end{array}$ & $\begin{array}{c}14.3 \\
7^{\mathrm{a}, \mathrm{b}}\end{array}$ & $\begin{array}{l}31 . \\
65\end{array}$ & $\begin{array}{c}4.1 \\
8^{\mathrm{a}}\end{array}$ \\
\hline $\begin{array}{c}\text { SDIA } \\
\text { F }\end{array}$ & 3.033 & $\begin{array}{c}933 \\
\mathrm{~b}\end{array}$ & $107.2^{\mathrm{a}, \mathrm{b}}$ & $\begin{array}{c}3.29 \\
\text { b }\end{array}$ & $\begin{array}{c}1.37 \\
\mathrm{~b}\end{array}$ & $\underset{\mathrm{a}}{41.6}$ & $1.76^{\mathrm{a}}$ & $\begin{array}{c}36 . \\
22\end{array}$ & $\begin{array}{c}19.0 \\
5^{\mathrm{a}}\end{array}$ & $\begin{array}{c}40 . \\
94\end{array}$ & $\begin{array}{c}4.9 \\
4^{\mathrm{a}}\end{array}$ \\
\hline $\begin{array}{c}\text { P- } \\
\text { value }\end{array}$ & & $\begin{array}{c}0.0 \\
028\end{array}$ & 0.0005 & $\begin{array}{l}<0 . \\
001\end{array}$ & $\begin{array}{c}0.00 \\
11\end{array}$ & $\begin{array}{l}<0 . \\
001\end{array}$ & $\begin{array}{c}<0.0 \\
01\end{array}$ & $\begin{array}{c}0.1 \\
325\end{array}$ & $\begin{array}{c}0.02 \\
60\end{array}$ & $\begin{array}{l}0.1 \\
647\end{array}$ & $\begin{array}{c}0.0 \\
002\end{array}$ \\
\hline
\end{tabular}

between treatments.

Table 4. Olive fruit chemical characteristics of fully irrigated (FI), regulated deficit irrigation (RDI), sustained irrigation (SDI) and sustained deficit irrigation applied by the farmer (SDIAF) treatments during three harvest dates. Total phenolic compounds (TPC, mg GAE g ${ }^{-1} \mathrm{DW}$ ), ortho-diphenols content (ODC, mg GAE g ${ }^{-1} \mathrm{DW}$ ), flavonoids (mg CE g ${ }^{-1} \mathrm{DW}$ ), total antioxidant capacity (TAC, mmol TE kg ${ }^{-1} \mathrm{DW}$ ), and fat content (\% of DW and \% of FW).

\section{TPC ODC Flavonoids TAC $\quad$ Fat content}

mg.g ${ }^{-1} \mathrm{DW} \quad \mathrm{mmol} \mathrm{kg}^{-1} \mathrm{DW} \%$ of DW \% of FW

\begin{tabular}{|c|c|c|c|c|c|c|}
\hline \multicolumn{7}{|c|}{$\begin{array}{l}\text { September } \\
19^{\text {th }}\end{array}$} \\
\hline FI & $29.3^{\mathrm{a}}$ & $46.6^{\mathrm{b}}$ & $30.7^{\mathrm{b}}$ & $99.9^{\mathrm{c}}$ & 19.5 & 6.7 \\
\hline RDI & $22.1^{b}$ & $36.8^{\mathrm{c}}$ & $31.2^{\mathrm{a}, \mathrm{b}}$ & $156.8^{\mathrm{b}}$ & 21.9 & 6.9 \\
\hline SDI & $25.2^{\mathrm{b}}$ & $48.9^{b}$ & $43.0^{\mathrm{a}}$ & $269.0^{\mathrm{a}}$ & 22.7 & 9.2 \\
\hline SDIAF & $30.6^{\mathrm{a}}$ & $60.5^{\mathrm{a}}$ & $38.5^{\mathrm{a}, \mathrm{b}}$ & $265.4^{\mathrm{a}}$ & - & - \\
\hline $\begin{array}{l}\text { P-value } \\
(\mathrm{P}<0.05)\end{array}$ & $<0.001$ & $<0.001$ & 0.0132 & $<0.001$ & 0.1694 & 0.1106 \\
\hline \multicolumn{7}{|c|}{ October $11^{\text {th }}$} \\
\hline FI & $12.2^{\mathrm{b}}$ & $41.5^{\mathrm{b}}$ & $24.7^{\mathrm{b}}$ & $119.9^{\mathrm{b}}$ & 40.6 & $15.4^{\mathrm{b}}$ \\
\hline RDI & $13.5^{\mathrm{a}, \mathrm{b}}$ & $48.8^{\mathrm{b}}$ & $27.1^{\mathrm{a}, \mathrm{b}}$ & $130.9^{b}$ & 45.5 & $18.3^{b}$ \\
\hline SDI & $14.3^{\mathrm{a}}$ & $53.9^{\mathrm{a}}$ & $30.9^{\mathrm{a}, \mathrm{b}}$ & $152.3^{\mathrm{a}, \mathrm{b}}$ & 46.3 & $23.8^{\mathrm{a}}$ \\
\hline SDIAF & $14.1^{\mathrm{a}}$ & $59.4^{\mathrm{a}}$ & $33.4^{\mathrm{a}}$ & $168.1^{\mathrm{a}}$ & - & - \\
\hline P-value & 0.0049 & $<0.001$ & 0.0087 & 0.0056 & 0.2090 & 0.0046 \\
\hline
\end{tabular}


$(\mathrm{P}<0.05)$

\begin{tabular}{lcccccc}
\hline October 25 $^{\text {th }}$ & & & & & & \\
FI & $26.6^{\mathrm{b}}$ & $65.9^{\mathrm{b}}$ & $26.3^{\mathrm{c}}$ & $220.4^{\mathrm{b}}$ & $37.7^{\mathrm{b}}$ & $14.9^{\mathrm{b}}$ \\
RDI & $26.9^{\mathrm{b}}$ & $80.9^{\mathrm{a}, \mathrm{b}}$ & $33.8^{\mathrm{b}}$ & $261.5^{\mathrm{b}}$ & $45.9^{\mathrm{a}}$ & $18.3^{\mathrm{a}}$ \\
SDI & $26.6^{\mathrm{b}}$ & $82.9^{\mathrm{a}}$ & $33.1^{\mathrm{b}}$ & $310.7^{\mathrm{a}}$ & $48.5^{\mathrm{a}}$ & $19.3^{\mathrm{a}}$ \\
SDIAF & $29.4^{\mathrm{a}}$ & $95.1^{\mathrm{a}}$ & $52.5^{\mathrm{a}}$ & $233.5^{\mathrm{b}}$ & $46.7^{\mathrm{a}}$ & $19.4^{\mathrm{a}}$ \\
P-value & & $\mathbf{0 . 0 0 0 7}$ & $<\mathbf{0 . 0 0 1}$ & $<\mathbf{0 . 0 0 1}$ & $\mathbf{0 . 0 1 0 7}$ & $\mathbf{0 . 0 1 9 5}$ \\
(P<0.05) & $\mathbf{0 . 0 0 1 2}$ & & & & &
\end{tabular}

differences $(\mathrm{P}<0.05)$ between treatments.

Table 5. Olive fruit phenolic composition of fully irrigated (FI), regulated deficit irrigation (RDI), sustained irrigation (SDI) and sustained deficit irrigation applied by the farmer (SDIAF) treatments during three harvest dates $\left(\mathrm{mg} \mathrm{kg}^{-1} \mathrm{DW}\right)$.

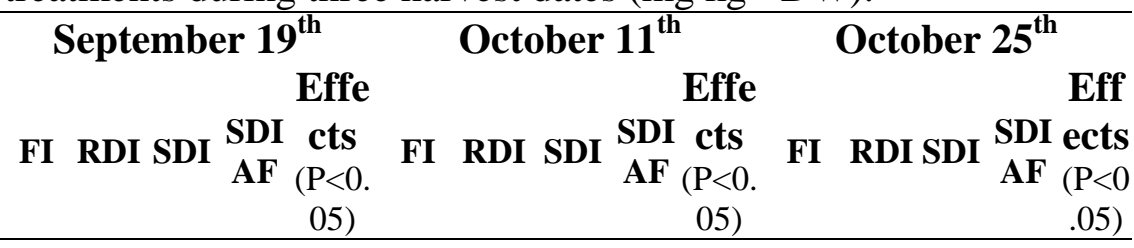

\section{Non-flavonoid composition}

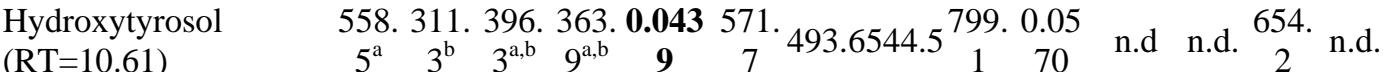

Oleuropein $(\mathrm{RT}=37.60) 1223126912213011 \mathbf{0 . 0 1 1} 17951790.1274 .130 \quad 0.673105 .465618361558 \mathbf{0 . 0 0}$

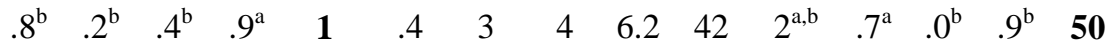

Chlorogenic acid 308. 301. 347. 410.0.307 534.608.4418.1835. 0.03 241.155.1 360. 531. 0.41 $\begin{array}{llllllllllllllll}(\mathrm{RT}=15.28) & 7 & 3 & 0 & 0 & 1 & 8^{\mathrm{a}, \mathrm{b}} & \mathrm{a}, \mathrm{b} & \mathrm{b} & 8^{\mathrm{a}} & \mathbf{6 5} & 241.1 & 55.1 & 7 & 0 & 57\end{array}$

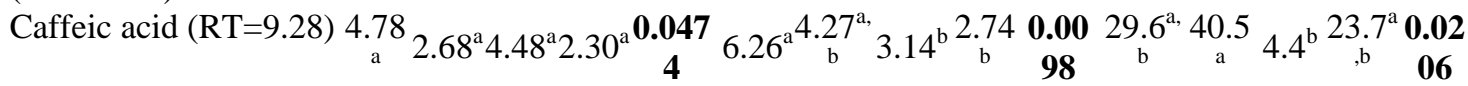

\section{Flavonoid composition}



Different letters within a line demonstrate significant differences $(\mathrm{P}<0.05)$ between treatments. n.d.- non detected. RT - retention time (min) 
Table 6. Olive fruit most representative fatty acids, and fatty acids saturated/unsaturated relations of fully irrigated (FI), regulated deficit irrigation (RDI), sustained irrigation (SDI) and sustained deficit irrigation applied by the farmer (SDIAF) treatments at final harvest. Saturated fatty acids (SFA), unsaturated fatty acids (UFA), monounsaturated fatty acids (MUFA), polyunsaturated fatty acids (PUFA).

\section{Treatment}

Fatty Acid Profile

$\%$ of total

\begin{tabular}{lccccc} 
& FI & RDI & SDI & SDIAF & P-value \\
\hline Palmitic acid (C16:0) & 17.03 & 15.60 & 15.58 & 16.98 & 0.2104 \\
Palmitoleic acid (C16:1) & $1.65^{\mathrm{a}}$ & $1.27^{\mathrm{b}}$ & $1.10^{\mathrm{b}}$ & $1.27^{\mathrm{b}}$ & $\mathbf{0 . 0 0 0 2}$ \\
Oleic acid (C18:1) & 68.09 & 71.51 & 70.72 & 69.59 & 0.2106 \\
Linoleic acid (C18:2) & $9.63^{\mathrm{a}}$ & $9.04^{\mathrm{a}, \mathrm{b}}$ & $10.05^{\mathrm{a}}$ & $8.28^{\mathrm{b}}$ & $\mathbf{0 . 0 1 1 8}$ \\
Linolenic acid (C18:3) & $1.42^{\mathrm{a}}$ & $1.08^{\mathrm{b}}$ & $1.12^{\mathrm{b}}$ & $1.57^{\mathrm{a}}$ & $\mathbf{0 . 0 0 0 8}$ \\
SFA & 17.92 & 16.17 & 16.15 & 16.82 & 0.0922 \\
MUFA & 70.68 & 73.54 & 72.56 & 73.18 & 0.0860 \\
PUFA & 11.40 & 10.29 & 11.28 & 10.00 & 0.0647 \\
UFA/SFA & 4.58 & 5.19 & 5.21 & 4.96 & 0.1125 \\
Oleic acid (C18:1) / Linoleic acid (C18:2) & $7.07^{\mathrm{a}}$ & $7.93^{\mathrm{a}}$ & $7.07^{\mathrm{a}}$ & $8.43^{\mathrm{a}}$ & $\mathbf{0 . 0 4 4 8}$
\end{tabular}

Different letters within a line demonstrate significant differences $(\mathrm{P}<0.05)$ between treatments. 

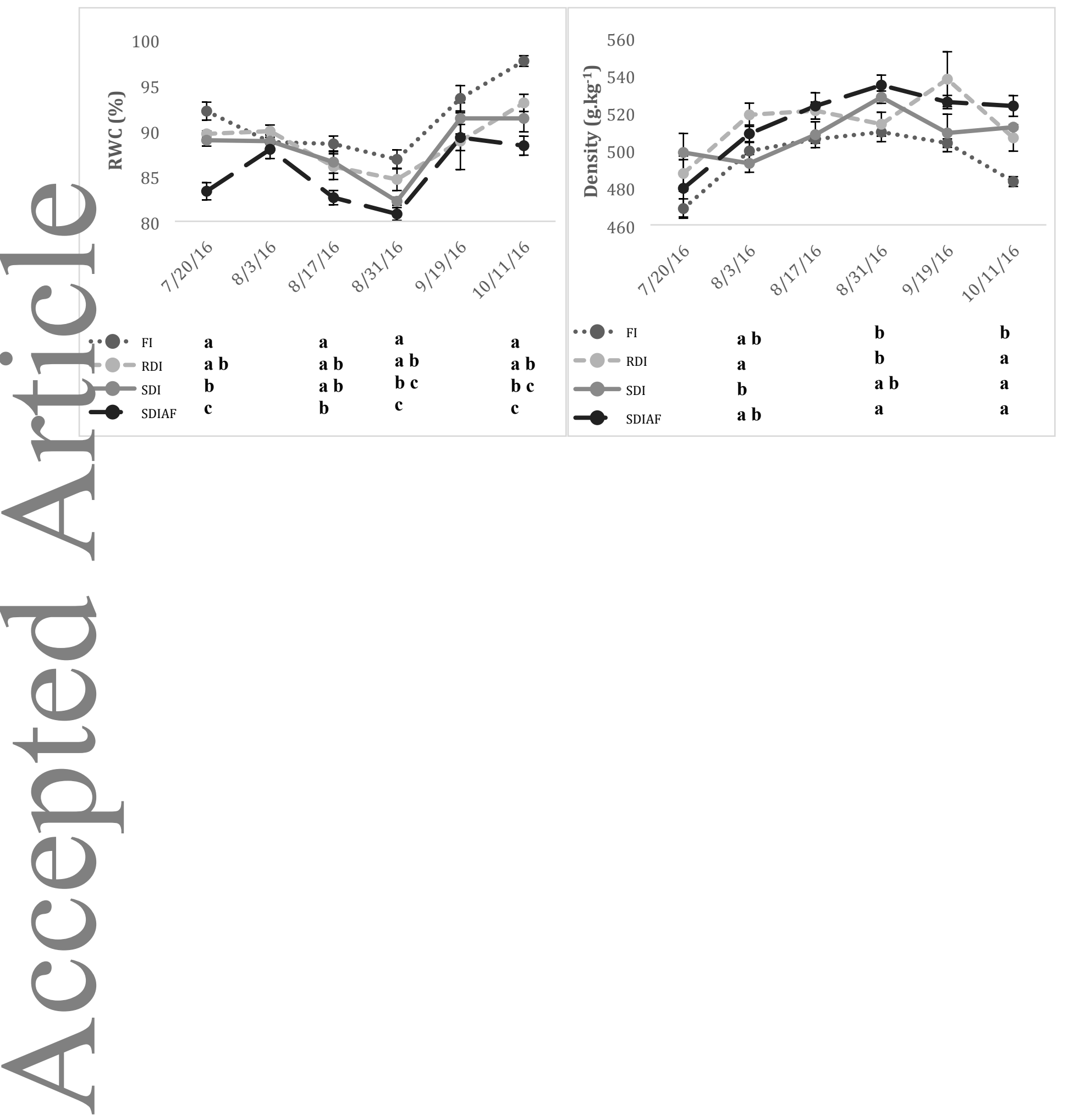


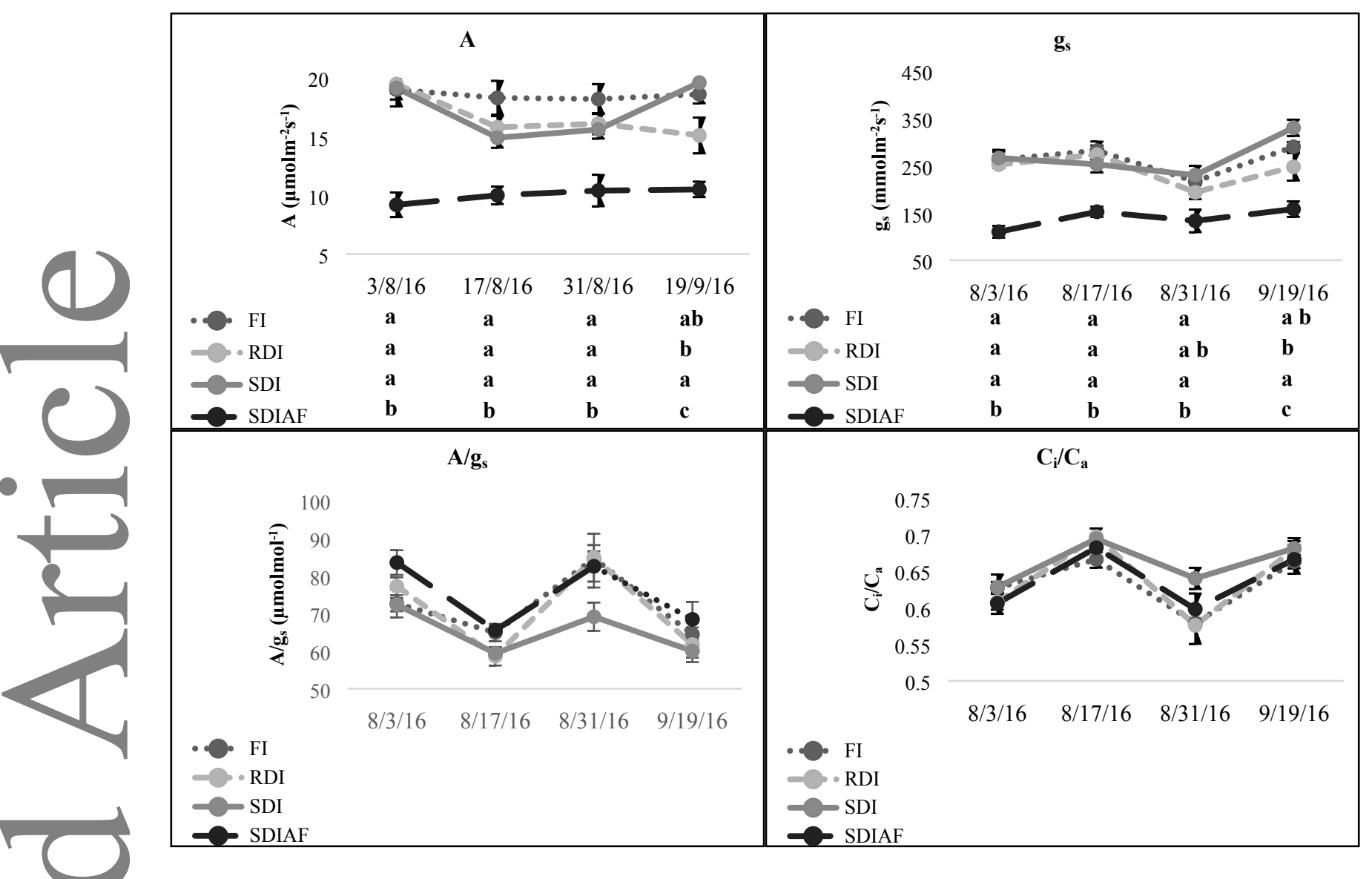

